\title{
De Novo Structural Determination of the Oligosaccharide Structure of Hemocyanins from Molluscs
}

\author{
Pavlina Dolashka ${ }^{1, *}$, Asya Daskalova ${ }^{1}$, Aleksandar Dolashki ${ }^{1}$ and Wolfgang Voelter ${ }^{2}$ \\ 1 Institute of Organic Chemistry with Centre of Phytochemistry, Bulgarian Academy of Sciences, \\ 1113 Sofia, Bulgaria; asya.daskalova@gmail.com or adaskalova@orgchm.bas.bg (A.D.); \\ adolashki@orgchm.bas.bg (A.D.) \\ 2 Interfacultary Institute of Biochemistry, University of Tuebingen, 72074 Tuebingen, Germany; \\ wolfgang.voelter@uni-tuebingen.de \\ * Correspondence: dolashka@orgchm.bas.bg or pda54@abv.bg; Tel.:+359-887193423
}

Received: 26 August 2020; Accepted: 23 September 2020; Published: 22 October 2020

\begin{abstract}
A number of studies have shown that glycosylation of proteins plays diverse functions in the lives of organisms, has crucial biological and physiological roles in pathogen-host interactions, and is involved in a large number of biological events in the immune system, and in virus and bacteria recognition. The large amount of scientific interest in glycoproteins of molluscan hemocyanins is due not only to their complex quaternary structures, but also to the great diversity of their oligosaccharide structures with a high carbohydrate content (2-9\%). This great variety is due to their specific monosaccharide composition and different side chain composition. The determination of glycans and glycopeptides was performed with the most commonly used methods for the analysis of biomolecules, including peptides and proteins, including Matrix Assisted Laser Desorption/Ionisation-Time of Flight (MALDI-TOF-TOF), Liquid Chromatography - Electrospray Ionization-Mass Spectrometry (LC/ESI-MS), Liquid Chromatography (LC-Q-trap-MS/MS) or Nano- Electrospray Ionization-Mass Spectrometry (nano-ESI-MS) and others. The molluscan hemocyanins have complex carbohydrate structures with predominant $N$-linked glycans. Of interest are identified structures with methylated hexoses and xyloses arranged at different positions in the carbohydrate moieties of molluscan hemocyanins. Novel acidic glycan structures with specific glycosylation positions, e.g., hemocyanins that enable a deeper insight into the glycosylation process, were observed in Rapana venosa, Helix lucorum, and Haliotis tuberculata. Recent studies demonstrate that glycosylation plays a crucial physiological role in the immunostimulatory and therapeutic effect of glycoproteins. The remarkable diversity of hemocyanin glycan content is an important feature of their immune function and provides a new concept in the antibody-antigen interaction through clustered carbohydrate epitopes.
\end{abstract}

Keywords: hemocyanins; molluscs; mass spectrometric analysis

\section{Introduction}

Glycoproteins are of great importance for the optimal and proper functioning of many bioactivities in the human body. Absence or alteration of glycoproteins can cause a wide range of diseases, e.g., the glycated form of haemoglobin is responsible for the onset of diabetes [1]. Glycans also play an important role in cardiovascular disease, microbial and viral pathogenesis, development of tumors, tissue repair, strengthening of the immune system, and others [2-4]. As demonstrated by various studies [5,6], hemocyanins have gained a large amount scientific interest due to their interesting glycoprotein structures. 
Hemocyanins are type-3 copper-binding proteins found freely dissolved in the hemolymph in two main phyla (mollusca and arthropoda), which have the same physiological function, but show significant differences in their structural organization and carbohydrate content.

Molluscan hemocyanins are among the largest known glycoproteins with huge cylindrical multimeric forms and molecular masses ranging from 3.3 to 13.5 MDa. They form decamers or multi-decamers of 330- to 550-kDa subunits organised by more than seven different functional units (FUs) with molecular masses ranging from 45 to $65 \mathrm{kDa}$. Structural subunits assemble to di-decamers as presented for keyhole limpet hemocyanin (KLH1) in (Figure 1) [7].

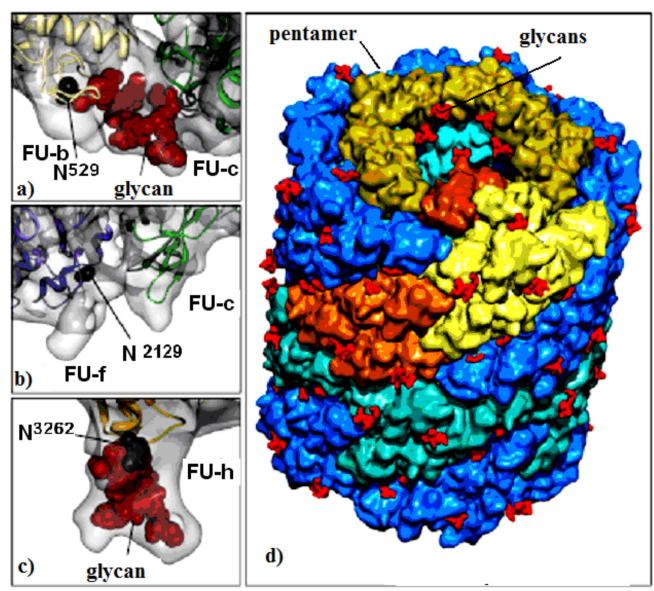

Figure 1. KLH1 subunit model. Location of Asp residue in the glycosylation site of: (a) FU-b and FU-c; (b) FU-f and FU-c; (c) FU-h; (d) di-decamer KLH1 model and the position of 120 glycans (marked in red) [7].

Their structure has been investigated using a combination of electron cryo-microsopy and X-ray crystallography (Figure 2). The represented X-ray crystal structure of the intact 3.8-MDa molecule of Todarodes pacificus squamous hemocyanin $(\mathrm{TpH})$ shows the complex oligosaccharide structures of the glycoprotein [8]. Chemical structure analysis of Todarodes pacificus hemocyanin revealed that the two most abundant sequences, HexNAcMan ${ }_{3} \mathrm{GlcNAc}_{2}$ and HexHexNAcMan${ }_{3} \mathrm{GlcNAc}_{2}$, accounted for more than $95 \%$ of all oligosaccharides tested in all individuals. The $\mathrm{Cu}_{2} \mathrm{O}_{2}$ cluster and the carbohydrates of functional unit " $\mathrm{d}$ " of TpH are represented in the 3D-model of Figure 2. The authors demonstrated the influence of glycans on the dissociation and re-association behavior of the decameric forms of $\mathrm{TpH}$ [9].

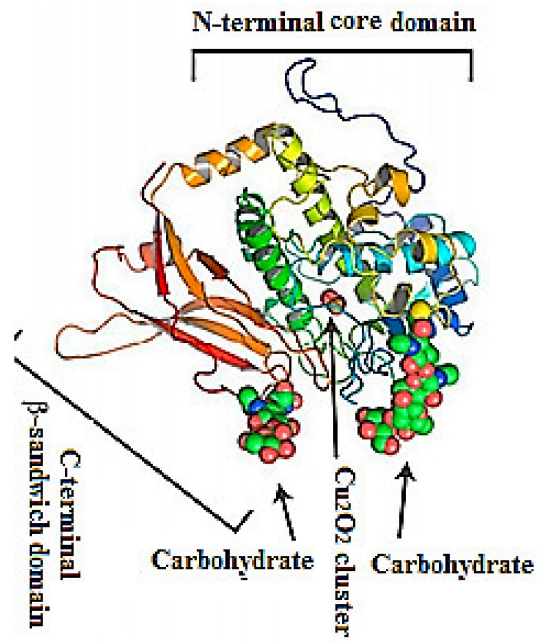

Figure 2. Representative ribbon diagram of FU-d of Todarodes pacificus squamous hemocyanin, colored as a ramp from blue (N-terminus) to red (C-terminus). The $\mathrm{Cu}_{2} \mathrm{O}_{2}$ cluster and carbohydrates [9]. 
Therefore, the great scientific interest in molluscan hemocyanins is due not only to their complex quaternary structures, but also to their great diversity in oligosaccharide structures, high carbohydrate content (2-9\%), specific monosaccharide composition [10-13], and their well-established link with the immunostimulatory effect $[14,15]$.

The studies on carbohydrate structures of hemocyanins from molluscs occupy an important part of this review, demonstrating significant differences in carbohydrate structures of molluscan hemocyanins.

\section{Carbohydrate Structures of Hemocyanins}

The first analyses of the carbohydrate structures of hemocyanins from the earth snail Helix pomatia $(\mathrm{HpH})$ [10], freshwater snail Lymnaea stagnalis (LsH) [16], and the California mussel (keyhole limpet) Megathura crenulata (KLH) [13,17] present complex carbohydrate structures composed predominantly of the monosaccharides Xyl, Fuc, Man, Gal, GalNAc, and GlcNAc. Along with common monosaccharides, other monosaccharides such as Xyl and O-methyl-Gal have also been identified in $\mathrm{HpH}$ glycans $[10,11,18]$. Though the $\mathrm{Xyl}$ residue is less common in glycoproteins from animal organisms, their presence is essential for immunogenic effects [10].

Other specifically-modified structures have been identified that bind ( $\beta 1-2) \mathrm{Xyl}$ residues to $\beta$-Man and $\alpha$-Fuc to 1,6-GlcNAc from the core of the glycan. Traces of large neutral N-glycans ending with 3-O-MeGal, Xyl, and/or Fuc monosaccharides have been found in Planorbarius corneus, Achatina fulica, and Arion lusitanicus [12,19]. The presented complete N-glycan spectrum of the slug Arion lusitanicus includes a combination of carbohydrate structures found in mammals, plants, insects, and the like [12,19]. Complex structures have also been published for some glycans of Rapana thomasiana hemocyanin $(\mathrm{RtH})$, later renamed Rapana venosa $(\mathrm{RvH})[11,20]$.

Furthermore, the studies on the carbohydrate structure of KLH, used in medicine, present two new $N$-linked glycans, Fuc( $\alpha 1-3)$ GalNAc( $\beta 1-4)[F u c(\alpha 1-3)]$ GlcNAc and Gal $(\beta 1-4) G a l(\beta 1-4) F u c(\alpha 1-6)$, as part of the huge protein molecule $[13,17]$. In one glycan, a Gal monosaccharide is linked to the final GalNAc, for which the clinical success of KLH in the treatment of bladder cancer is found. The carbohydrate chain $\operatorname{Gal}(\beta 1-4) \mathrm{Gal}(\beta 1-4) \mathrm{Fuc}(\alpha 1-6)$ is linked to the nucleus of another glycan, which also contributes to the use of KLH in immunotherapy.

The structural diversity of $N$-glycans in snails has been investigated very thoroughly by a number of authors who report predominantly high-mannose carbohydrate chains. Exceptions were found for some carbohydrate structures that bind sialic acid, $\alpha 1-6$ - and $\alpha 1-3-F u c, \beta 1-2-X y 1$, MeMan, MeGal, GlcNAc, GalNAc, and other monosaccharides, but significantly fewer glycans end up with a 3-O-MeMan residue $[10,11,18]$.

A great variety of oligosaccharide structures has also shown for side chains linked to carbohydrate structures of hemocyanins from the abdominal mollusc Lymnaea stagnalis, the California mussel $\mathrm{KLH}$, and others $[12,14,16,19,21]$. Specific enzymes, responsible for the formation of these complex structures, have been found in various organs and tissues of Limax maximus, Lymnaea stagnalis, and other representatives of the molluscs [12].

Important information for the positions of glycosylated Asn residues for three FU-s (FU-b, FU-f and FU-h) is provided by the di-decameric model of KLH1 (Figure 1a-d). The model shows 120 potential $N$-glycan motifs (NXT and/or NXS), located mainly on the surface of the molecule (Figure 1d). FU-c is of special interest due to its absence of a residual glycan (Figure 1b) [22]. This corresponds to KLH-c with only one O-glycosylation site, lacking an attached, glycan moiety [23]. The absence of glycan in FU-c was also observed in hemocyanins of Haliotis tuberculata $(\mathrm{HtH})$, Octopus dofleini (OdH), and Aplysia californica (AcH) [24]. Published literature mostly presents O-glycosylated hemocyanins of the arthropodan species, while very few O-linked glycans have been found in hemocyanins of the Molluscs.

Another interesting feature for molluscan and arthropodan hemocyanins is the position of the putative glycosylation sites, located mainly on the surface of the molecule. Two N-linked sites of FU $\mathrm{HtH} 1-\mathrm{h}$ are located at rather unusual positions and are not found in other FUs, including HtH2-h. 
These glycans probably perform an important role related to the function of glycosylated FU-h, suggesting that they prevent binding of decamers to di-decamers and formation of multi-decamers in hemocyanins. The assumption is confirmed by the established absence of multi-decamers in the hemocyanins of $\mathrm{AcH}$ and $\mathrm{HtH} 1$ [24,25].

In this review, the oligosaccharide structures of three hemocyanins are presented: from the Black Sea snail Rapana venosa, the garden snail Helix lucorum, and the abalone Haliotis tuberculata, which normally exist under different living conditions. They have been compared with the well-studied oligosaccharide structure of keyhole limpet hemocyanin (KLH) from a mussel inhabiting the northern coast of America, and other hemocyanins with complex carbohydrate structures.

Mass spectral methods and techniques are appropriate for analysis of glycoproteins and identification of their structure. To determine molecular masses of amino acid sequences (AAS) of proteins and peptides, mass spectrometry is used as the nucleus of proteomics. It is one of the most widely used methods for the analysis of biomolecules like peptides, proteins, and glycoproteins, with a series of sophisticated instrumentations such as Matrix Assisted Laser Desorption/Ionisation-Time of Flight (MALDI-TOF-TOF), Liquid Chromatography-Electrospray Ionization-Mass Spectrometry (LC/ESI-MS), Liquid Chromatography (LC-Q-trap-MS/MS) or NanoElectrospray Ionization-Mass Spectrometry (nano-ESI-MS).

\section{Carbohydrate Structure of Hemocyanins from the Marine Snail Rapana venosa}

Recent research reported on the glycosylated nature of $\mathrm{RvH}$, with a carbohydrate content of $8.9 \%$, which differs for the two subunits $\mathrm{RvH} 1(12.4 \%)$ and $\mathrm{RvH} 2(4.4 \%)[26,27]$. A new strategy for analysis and determination of the carbohydrate structure of subunits and $\mathrm{FUs}$ of $\mathrm{RvH}$ is presented here (Figure 3).

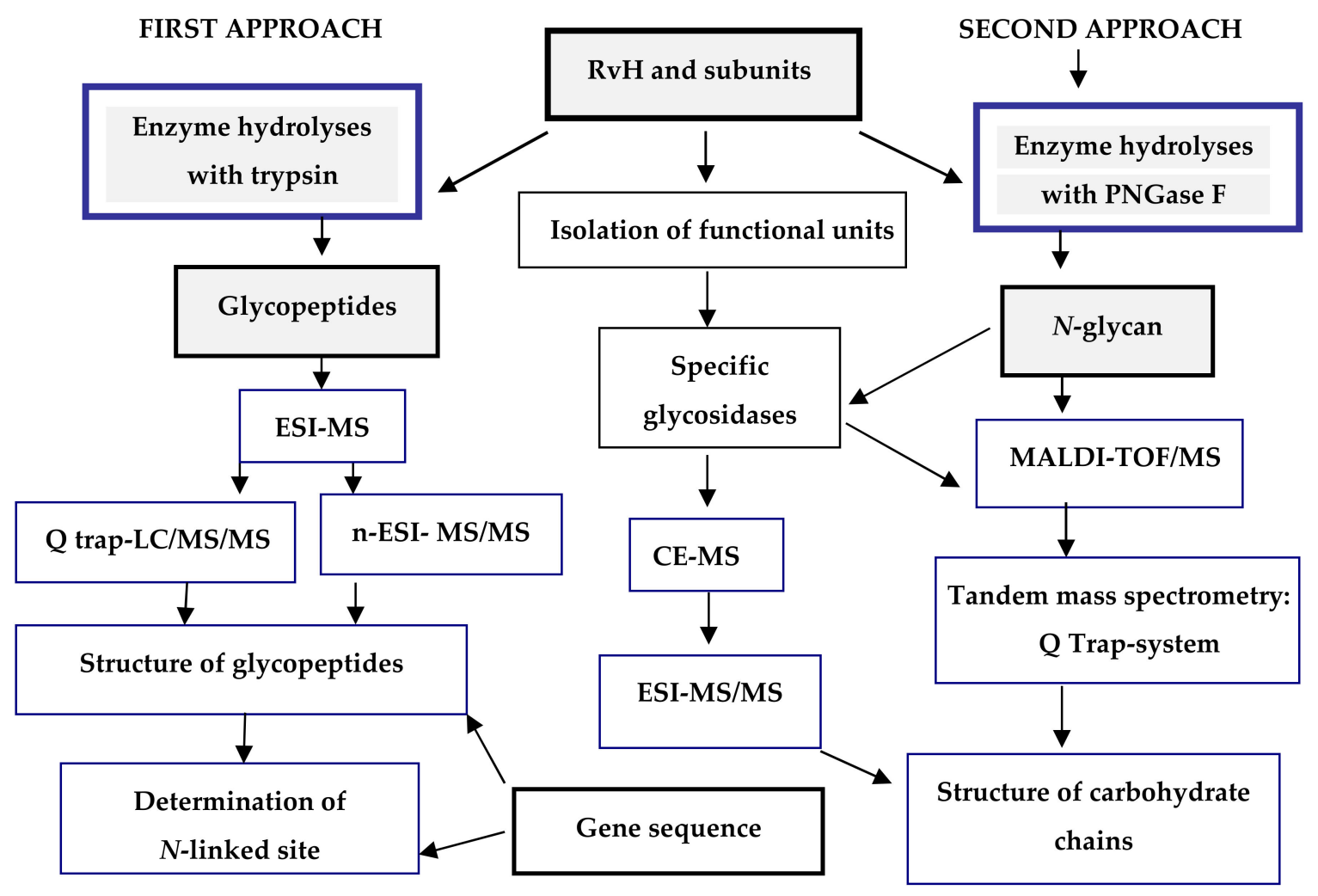

Figure 3. Scheme for analysis and determination of the carbohydrate structure of RvH1, RvH2 and FUs. On the basis of this strategy, two main approaches are involved. 
In the first approach, functional units (FUs) of the two subunits $\mathrm{RvH} 1$ and $\mathrm{RvH} 2$ are treated with trypsin and the obtained glycopeptides are identified through LC/ESI-MS, LC-Q-trap-MS/MS or nano-ESI-MS [28-33]. The second approach includes isolation of glycans after hydrolysis of the subunits of RvH with specific glycosidases (PNGase F) and analysis of the glycan structures with MALDI-TOF-MS, CE-MS, and Q-trap instrumental systems [28,29,34].

\subsection{First Approach for Determination of the Carbohydrate Structure of $\mathrm{RvH}$}

The developed strategy is suitable for the determination of the complex carbohydrate structures of molluscan hemocyanins. The first approach of the developed and implemented strategy provides information about the oligosaccharide structures only for the $\mathrm{RvH}$.

\subsubsection{Isolation and Characterization of Glycopeptides of FUs from RvH}

Three FUs (RvH1-a, RvH1-f, and RvH1-b) are isolated after trypsinolysis of RvH1 and the resulting fragments are separated on a Superdex 300 column. The positive orcinol $/ \mathrm{H}_{2} \mathrm{SO}_{4}$ test allows one to detect two (Glp1 and Glp2) glycopeptides in RvH1-a, but only one (Glp3) in RvH1-f. Confirmation of the complex carbohydrate structures of the three glycopeptides (Glp1, Glp2, and Glp3) is presented after treatment with various glycosidases and analysis with CE-MS and ESI-MS.

Detailed data for the structures of three glycopeptides from RvH1 (Glp1, Glp2, and Glp 3) are received after treatment with specific glycosidases and analysis of cleaved products with CE-MS and ESI-MS. That allows the identification of complex bi-antennary structures of the glycans including methylated galactoses bound to Glp1 and Glp2 differing from the structure of the glycopeptide Glp3 of RvH1-f [28,29].

With these published data on the carbohydrate structures of molluscan hemocyanins, methylated monosaccharides are mentioned, as found before, as constituents in seven related complex structures, constituents of the hemocyanins from Lymnaea stagnalis [16].

\subsubsection{Structures of Glycopeptides from RvH, Determined Through LC/ESI-MS, Nano-ESI-MS and} Q-trap LC/MS/MS Systems

After trypsinolysis of the two subunits, $\mathrm{RvH} 1$ and $\mathrm{RvH} 2$, and separation of fragments on a Nucleosil 7 C18 column, mass spectrometric methods were applied for structure determination of glycopeptides [28]. The presented orcinol $/ \mathrm{H}_{2} \mathrm{SO}_{4}$ test (Figure 4) gives positive reactions only for 58 eluted fractions from the column. The oligosaccharide structures of the glycopeptides were determined through tandem-MS after tracking of the fragmented ions from the MS/MS data of the double-charged ion $[\mathrm{M}+2 \mathrm{H}]^{2+}$ and scanning of the pseudo-MS/MS/MS.

12534566789910111213141516

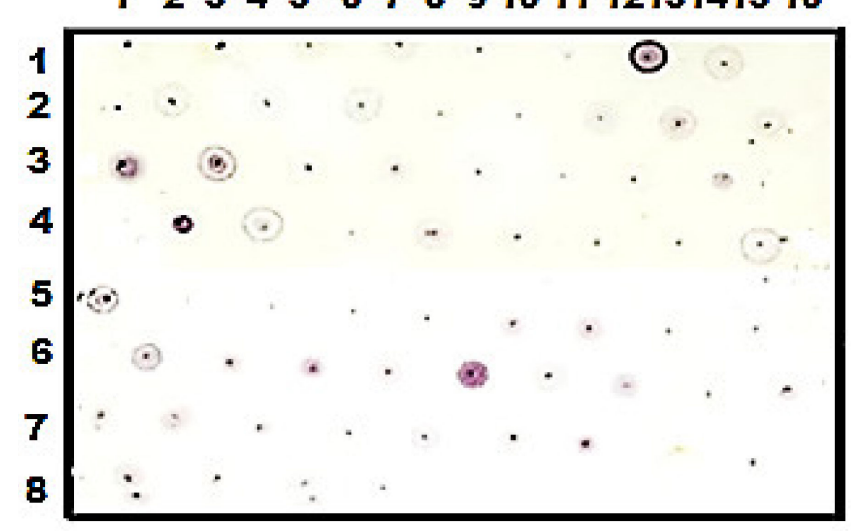

Figure 4. Orcinol $/ \mathrm{H}_{2} \mathrm{SO}_{4}$ test of the obtained fractions of $\mathrm{RvH} 1$ after trypsinolysis. 
The summary of the results obtained from $\mu$ LC/ESI-MS analysis after tryptic hydrolysis of RvH1 provide additional confirmation for the glycosylation of RvH1: three glycopeptides were identified with Mw 2745.5 Da, 2421.0 Da, and 2907.1 Da, and oligosaccharide structures of the high-mannose type [26,35]. Data for the carbohydrate structure of $\mathrm{RvH}$ was completed with the comprehensive nano-ESI-MS analysis of isolated $\mathrm{RvH} 1$ and $\mathrm{RvH} 2$ glycopeptides after trypsinolysis. This methodology gives simultaneous access to fundamental structural characteristics of the glycoproteins, such as their glycan structure, amino acid sequences (AAS), and binding sites of glycans to the peptide chains [31]. The structure of the glycopeptides are determined after the interpretation of the $Y$ - and B-ions represented in the spectrum, giving information about the calculated glycopeptide, with $\mathrm{Mw}$ 2676.32 Da, and ion, with $\mathrm{m} / z 1338.16[\mathrm{M}+2 \mathrm{H}]^{2+}$ (Figure 5). Another important feature from the MS/MS spectrum is the bound glycan (GlcNAc residue) at the ion at $m / z 1661.71$ to the $N$-glycosylated peptide (R-) at $m / z 1459.75[\mathrm{M}+\mathrm{H}]^{+}$. The glycan-typical oxon ions [M+H] ${ }^{+}$with $m / z 204.08$ (HexNAc) and $m / z 366.15$ (HexHexNAc) in the MS/MS spectrum show the exact structure of the glycan and the bound peptide. The glycopeptide characteristic is complemented by the represented different single fragment $[\mathrm{M}+\mathrm{H}]^{+}$glycan ions with $m / z 528.20$ (Hex ${ }_{2} \mathrm{HexNAc}$ ), $m / z 690.27$ (Hex ${ }_{3} \mathrm{HexNAc}$ ), $m / z$ 852.31 (Hex ${ }_{4} \mathrm{HexNAc}$ ), and $m / z$ 1014.46 (Hex ${ }_{5} \mathrm{HexNAc}$ ) (Figure 5).

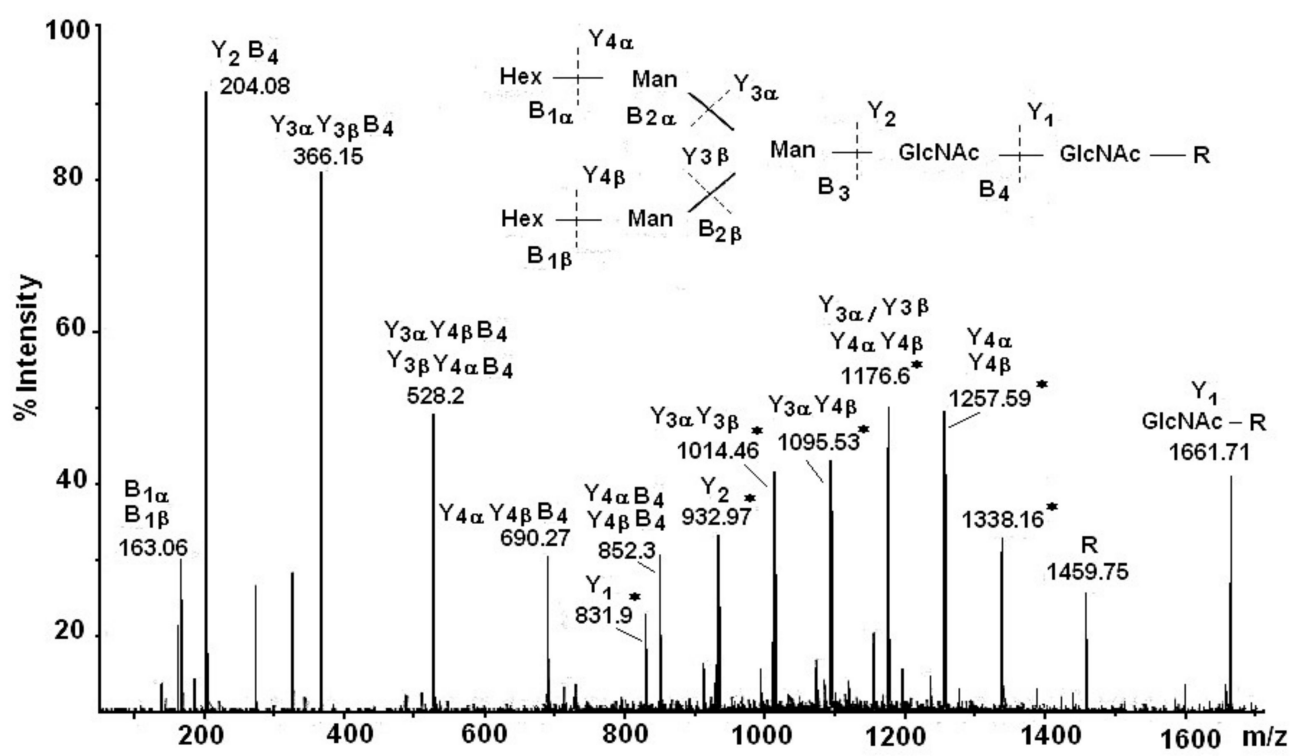

Figure 5. Nano-ESI- MS/MS analysis of the glycan G1, bound to glycopeptides, presented as an ion at $m / z 1338.16[\mathrm{M}+2 \mathrm{H}]^{2+}[31]$.

The results of the nano-ESI-MS analysis of the glycopeptide with Mw 2676.3 Da confirm the highly mannose-like carbohydrate structure of $\mathrm{RvH}$ [31]. The assumption of the carbohydrate structure of RvH1 was confirmed by the combined analysis of glycopeptides with LC/MS and the Q-trap system. The resulting LC/MS/MS chromatogram of the eluted fraction at $31.24 \mathrm{~min}$ at high scanning resolution expressed a dominant ion with $m / z 837.97[\mathrm{M}+3 \mathrm{H}]^{3+}$, corresponding to a glycopeptide with $\mathrm{Mw}$ 2511.91 Da. The fragment $Y$ - and B-ions with $\mathrm{m} / \mathrm{z} 204.1,366.2,528.3,690.5$, and 852.4 determine the carbohydrate structure as $\mathrm{Hex}_{2} \mathrm{Man}_{2} \mathrm{GlcNAc}_{2}$ of a glycan with $\mathrm{Mw}$ 1054.0 Da. The other fragmented $y$ - and b-ions reflect the amino acid sequence AAS of the peptide MGQYGD (I/L) STNNTR with two potential glycosylation sites (-D(L/I) S- and -NNT-) (Figure 6). According to LC/MS and Q-trap analysis, only one glycosylation site (-NNT) in a glycopeptide with Mw $2511.91 \mathrm{Da}$, to which a high mannose glycan $\mathrm{Hex}_{2} \mathrm{Man}_{2} \mathrm{GlcNAc}_{2}$ with $\mathrm{Mw}$ 1054.0 Da is linked, can be detected [31]. 


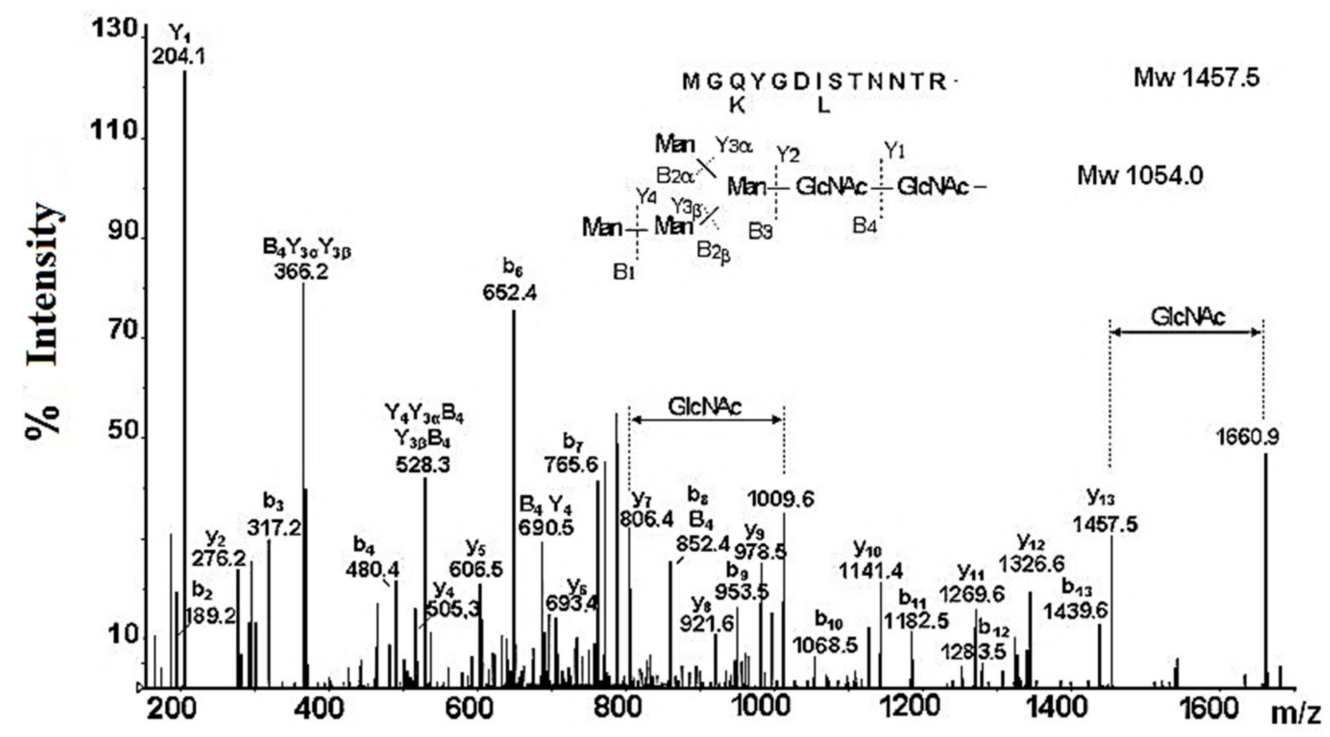

Figure 6. Enhanced product ion (EPI)—scanning of an ion with $m / z 837.97[\mathrm{M}+3 \mathrm{H}]^{3+}$ with a higher resolution.

\subsection{Second Approach for Determination of Carbohydrate Structure of $R v H$}

Interpretation of the structure of glycopeptides is often difficult due to the overloaded MS spectra via fragmented ions of both the peptide (y-and b-ions) and the glycan (Y-and B-ions). This disadvantage is solved by a second approach. After treatment with the specific glycosidase PNGase, F glycans are removed from the subunits $\mathrm{RvH} 1$ and $\mathrm{RvH} 2$ [32,33], eluted with $2 \mathrm{~mL} 25 \% \mathrm{ACN} / 0.05 \%$ TFA through a Carbograph column and finally analysed by CEand MALDI-TOF, presenting the high mannose character of glycan structures including Gal, Fucand $\mathrm{Xyl}$ in the carbohydrate chains of RvH1 and $\mathrm{RvH} 2$ [32].

\subsubsection{Analysis of N-Glycans from RvH by Capillary Electrophoresis Combined with MS Analysis}

The approach of CE with MS allows structure identification of glycans in very low concentration mixtures. Moreover, using this method, a new type of structure was presented for the ion at $\mathrm{m} / \mathrm{z} 555.7$ $[\mathrm{M}-3 \mathrm{H}]^{3-}$ of the glycan from $\mathrm{RvH} 1$, which was different from structures published by other authors. Giles et al. 2005 published one MeHex residue connected to an inner Fuc residue (Figure 7A, B) [33].

The analyses of CE-MS/MS show the complex structures of the glycans of RvH1 presented by ions at $m / z 555.7[\mathrm{M}-3 \mathrm{H}]^{3-}$ and two isomeric forms of the glycan with identical MS/MS spectra. The identical MS/MS spectra demonstrate essential divergences in the structure of glycan in connection to the GlcNAc residue at $\alpha-1,3$ or $\alpha-1,6$-positions in the trisaccharide of the glycan. Moreover, this structure resembles the published structure from Gielens and co-authors with an internal GalNAc residue and MeHex [11] (Figure 7A).

The used methods cannot differentiate the two structures of MeHex and HexA because of the small difference in the $\mathrm{Mw}$ from $0.036 \mathrm{Da}$. This problem was solved by CE-MS/MS analyses, which determined the methylated structure of the oligosaccharide, whose behavior does not correspond to the glycan at $m / z$ 555.7. Larger glycans will migrate faster than smaller ones, and charged oligosaccharides will migrate slower than their neutral counterparts. A glycan, detected at $m / z 555.7$ as a 4 -fold negatively charged ion, migrates slower than glycan, which is smaller and detected at $m / z 557.8$ as 3 times negatively charged ion.

Based on this, we can conclude that the ion at $m / z 555.7$ corresponds to a charged N-glycan and a complex glycan with an internal fucose connecting a hexuronic acid (HexA) and an $\mathrm{N}$-acetylhexosamine (HexNAc). Similar structures with HexA and Fuc residues are suggested from MS/MS analyses and 
the observed electrophoretic offset of the three ions $[\mathrm{M}-4 \mathrm{H}]^{4-}$ in $\mathrm{RvH}$. The specific structures with HexA in RvH1 are most possibly a result of the oxidizing environment [33].
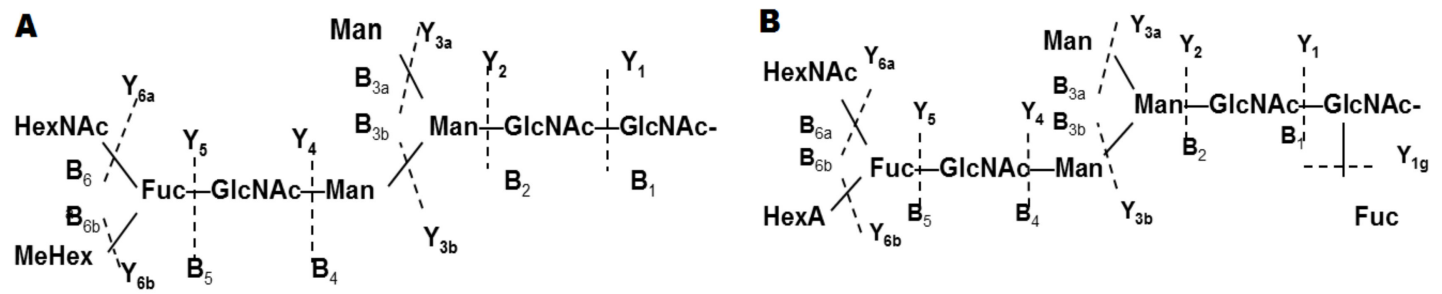

Figure 7. The complex structures presented for the ion at $m / z 555.7[\mathrm{M}-3 \mathrm{H}]^{3-}$ of $\mathrm{RvH} 1$ analyzed by CE-MS/MS and MS/MS spectra: (A) Structure presented by Giles et al. 2005 [11]; (B) Structure presented by Sandra et al. 2007 [33].

\subsubsection{Analysis of Glycans from RvH by 3-AP- and APTS-Labeled Glycans}

A new combined approach of CE-MS and MS/MS analyses of labeled glycans of RvH1 with positively charged 3-aminopyrazole (3-AP) is suitable to determine glycan structures at very low concentrations in mixtures. A comparative analysis of the behaviour of the 3-AP-labeled glycans shows a shift of the elution time in the chromatogram [33].

Another important piece of information is the structural differences of glycans with identical isomer MS/MS spectra, which is probably due to the acid tetrasaccharide attached to the $\alpha-1,3$ or $\alpha-1,6$-arm positions of the trimannose core. Proof for this is the reported difference from the additional Fuc residue in the MS/MS spectra of the ion with $m / z 853.7[\mathrm{M}+2 \mathrm{H}]^{2+}$ (Figure 8A) and with $m / z 926.8$ $[\mathrm{M}+2 \mathrm{H}]^{2+}$ (Figure 8B).
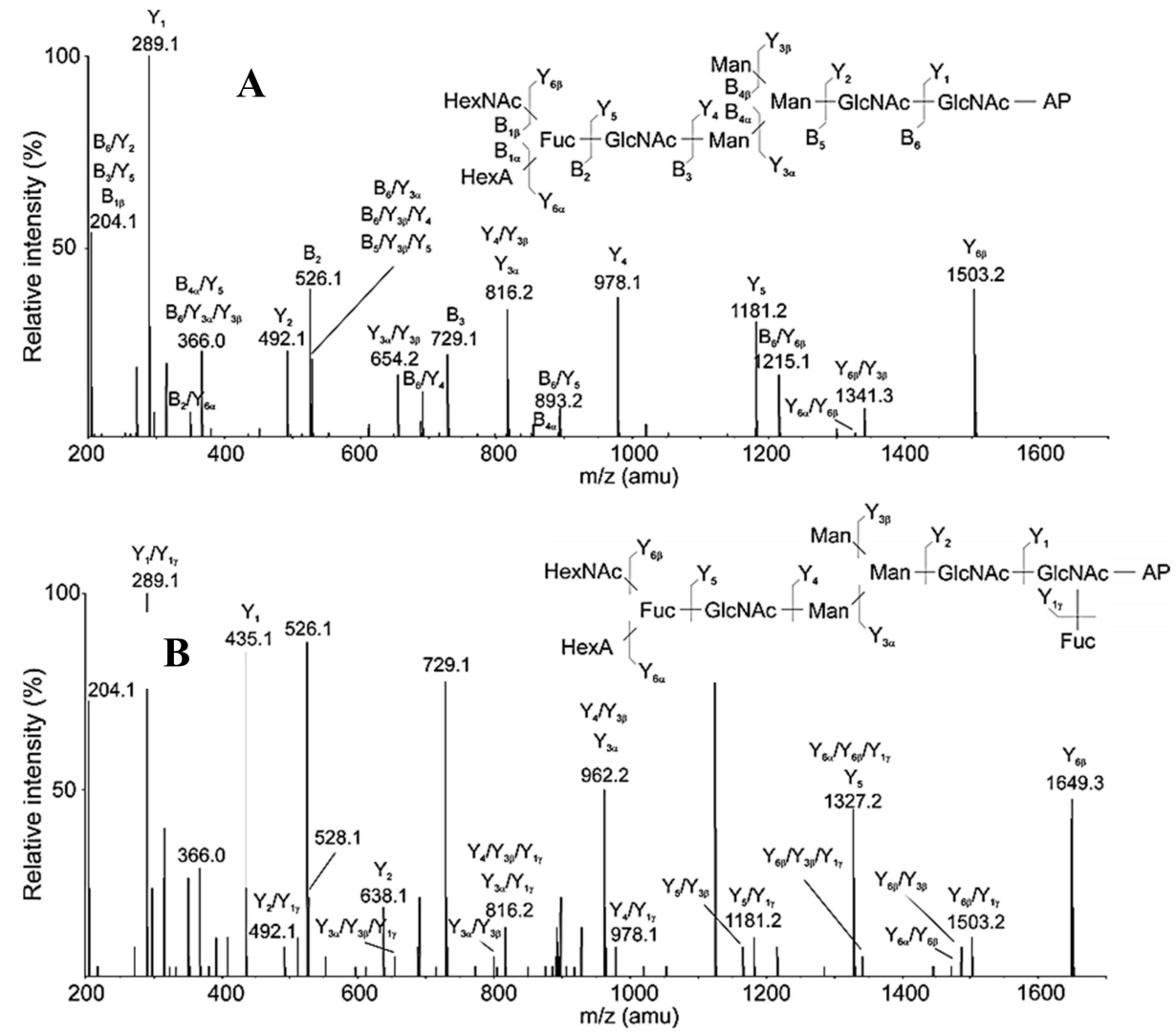

Figure 8. (A). MS/MS analysis of 3-AP-glycan from $\mathrm{RvH}$ with $\mathrm{m} / z 853.7[\mathrm{M}+2 \mathrm{H}]^{2+}$ eluted at $14.87 \mathrm{~min}$. (B) MS/MS analysis of 3-AP-glycan from $\mathrm{RvH}$ with $\mathrm{m} / z 926.8[\mathrm{M}+2 \mathrm{H}]^{2+}$, eluting at $14.87 \mathrm{~min}$. 
Confirmation of the position of the triple moiety (HexNAcFucHexA) is ion $\mathrm{B}_{2}$ with $m / z 526.1$ $[\mathrm{M}+\mathrm{H}]^{+}$, indicating the loss of the Fuc residue after separation from the HexNAc and HexA residue. The advantage of the applied approaches is the identification of the complex structures of two glycans FucHexAHexNAcGlcNAcMan GlcNAc $_{2}$ and $\mathrm{Fuc}_{2} \mathrm{HexAHexNAcGlcNAc}_{2} \mathrm{Man}_{3} \mathrm{GlcNAc}_{2}$, respectively.

3.2.3. Determination of Hexuronic Acid in the Structure of RvH1 After Amidation and Permethylation of the Glycans

This new method is based on the modification of the carboxyl groups of the glycan with $\mathrm{NH}_{4} \mathrm{Cl}$ and DMT-MM [4-(4,6-dimethoxy-1,3,5-triazin-2yl)-4-methyl-morpholinium chloride], whereby the carboxylic acid is converted to an amide, leading to a decrease in the Mw of acidic glycans by $0.9840 \mathrm{Da}$, identifying a bound HexA moiety of the glycan [33]. MALDI-MS analysis reported a decrease in Mw for eight $\mathrm{N}$-linked glycans in $\mathrm{RvH} 1$ after amidation, demonstrating the involvement of eight HexA in glycans of RvH1. The conversion of HexA to MeHex shows an increase in Mw by 14 Da after permethylation of the four identified glycans, noted in Table 1 as 14, 17, 19 and 21 [32,33].

Table 1. Composition of N-glycans in RvH1. (a) N-glycans are represented as $[\mathrm{M}+\mathrm{Na}]^{+}$ions. Mw of permethylated glycans is indicated in parentheses. (b) $\mathrm{m} / \mathrm{z}$ values of APTS-labeled glycans [33].

\begin{tabular}{|c|c|c|c|c|c|}
\hline № & Structure & 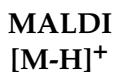 & № & Structure & $\begin{array}{l}\text { MALDI } \\
\text { [M-H }^{+}\end{array}$ \\
\hline 1 & FucMan2GlcNAc2 & 917.3 & 12 & Man7GlcNAc2 & 1581.7 \\
\hline 2 & Man3GlcNAc2 & 933.3 & 13 & Fuc2HexNAc2Man3GlcNAc2 & 1631.8 \\
\hline 3 & FucMan3GlcNAc2 & 1079.5 & 14 & FucHexAHexNAc2Man3GlcNAc2 & 1661.7 \\
\hline 4 & Man4GlcNAc2 & 1095.5 & 15 & FucHexNAc3Man3GlcNAc2 & 1688.8 \\
\hline 5 & HexNAcMan3GlcNAc2 & 1136.5 & 16 & Man8GlcNAc2 & 1743.7 \\
\hline 6 & FucMan4GlcNAc2 & 1241.6 & 17 & Fuc2HexAHexNAc2Man3GlcNAc2 & 1807.8 \\
\hline 7 & Man5GlcNAc2 & 1257.6 & 18 & Fuc2HexNAc3Man3GlcNAc2 & 1834. \\
\hline 8 & FucHexNAcMan3GlcNAc2 & 1282.6 & 19 & FucHexAHexNAc3Man3GlcNAc2 & 1864.8 \\
\hline 9 & HexNAc2Man3GlcNAc2 & 1339.6 & 20 & Man9GlcNAc2 & 1905.8 \\
\hline 10 & Man6GlcNAc2 & 1419.6 & 21 & Fuc2HexAHexNAc3Man3GlcNAc2 & 2010.8 \\
\hline 11 & FucHexNAc2Man3GlcNAc2 & 1485.7 & & & - \\
\hline
\end{tabular}

Another important method for determination of complex structures of the glycans in RvH is Q-trap analyses of permethylated glycans. The presented MS/MS spectra of structures with tetrasaccharide are expressed by two ions with $m / z 660.3[\mathrm{M}+\mathrm{Na}]^{+}\left(\mathrm{B}_{3} / \mathrm{Y}_{6 \beta}\right)$ and $919.4[\mathrm{M}+\mathrm{Na}]^{+}\left(\mathrm{B}_{3}\right)$ (Figure 9). The position of the Fuc residue in the chain was confirmed by additional $\mathrm{MS}^{3}$ analysis of the permethylated $\mathrm{B}_{3}$ ion. The reported change in Mw by 160 Da [145+14] probably reflects methylation of only one hydroxyl group of the glycan because the other three hydroxyl groups participate in other bonds. Evidence of acidic carbohydrate structures is also presented in the $\mathrm{RvH} 2$ subunit. They are reported based on the change in molecular masses with $1 \mathrm{D}$ of two glycans from the glycan mixture of RvH2 before and after amidation [32].

Further interesting carbohydrate structures are also presented in RvH1 and RvH2 by Q-trap analyses of the obtained glycans after treatment of both subunits with PNGase F glycosidase, specific for N-glycosylation. This approach proved to be very suitable for determination of the structures of 25 glycans from RvH1 and 28 glycans from RvH2. Glycan structures with one HexNAc residue and HexA bound in an oligosaccharide of $\mathrm{RvH}$ to an internal Fuc residue have been demonstrated [32,33]. 


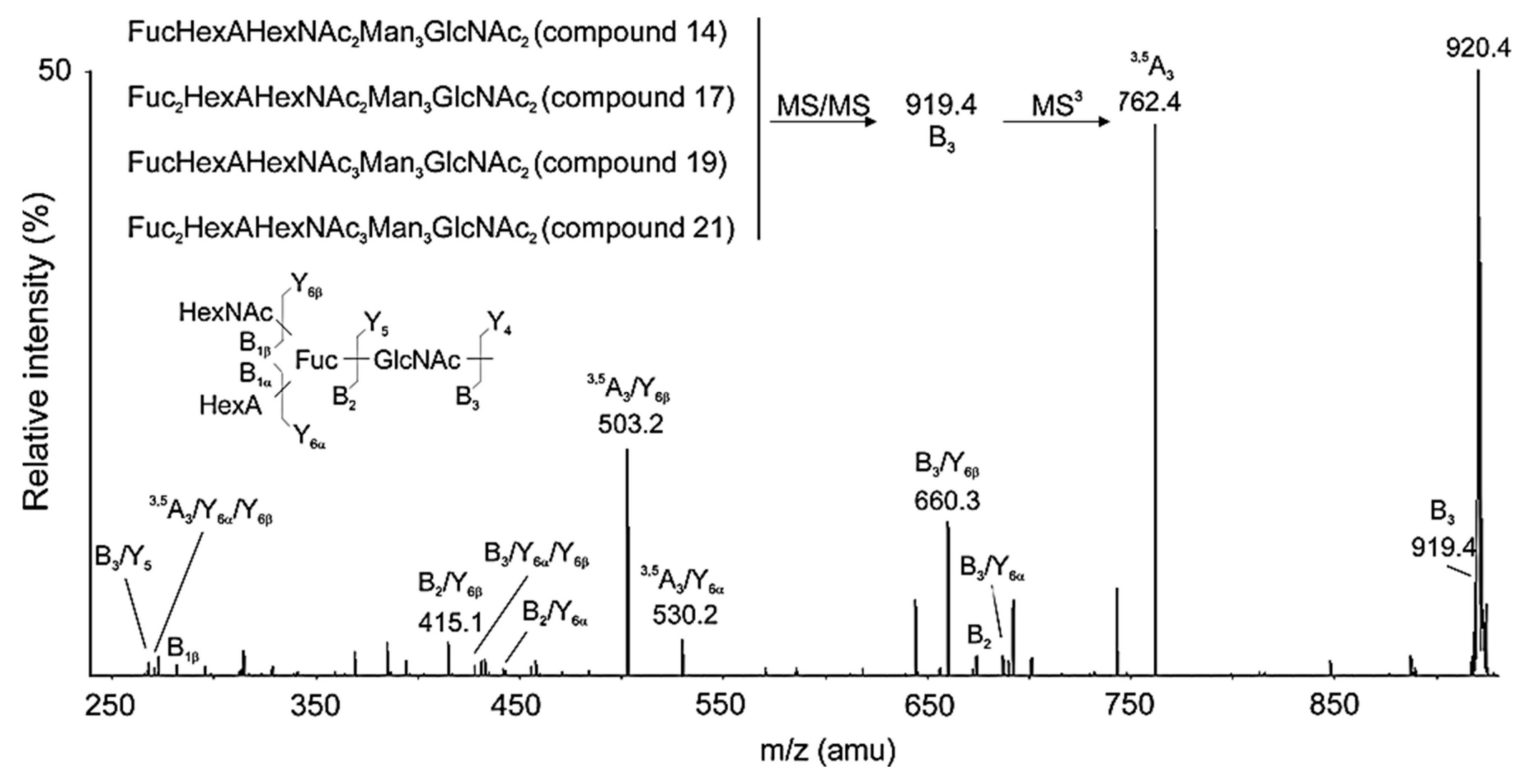

Figure 9. $\mathrm{MS}^{3}$ spectrum of the $\mathrm{B}_{3}$ ion with $m / z 919.4[\mathrm{M}+\mathrm{Na}]^{+}$(tetrasaccharide), after methylation of acid glycan from $\mathrm{RvH} 1$ with $\mathrm{m} / \mathrm{z} 1038.5[\mathrm{M}+2 \mathrm{Na}]^{2+}$ (structural information including permethylated sites).

\subsubsection{Structures of the N-Glycans of RvH1 and $\mathrm{RvH} 2$ Determined by the Q-trap System}

The comparison of the data obtained from the various employed methods and techniques determines the complex carbohydrate structure of Rapana venosa hemocyanin, similar to that observed for most molluscan hemocyanins. With the new methods developed, rare carbohydrate moieties of glycans, such as MeHex residues, have been detected. For the first time, a new class of glycans with an $\alpha 1,6-F u c$ residue bound to HexA and HexNAc has been discovered for hemocyanins.

\section{Carbohydrate Structure of Hemocyanins from Helix lucorum}

New methods and approaches for analyzing the carbohydrate structure of hemocyanin from the snail Helix lucorum $(\mathrm{HlH})$ show a complex carbohydrate structure (Figure 10). The glycans obtained after treatment of $\beta \mathrm{c}-\mathrm{HlH}$ with PNGase F are determined by MALDI-MS analyses, mainly as triple charged $[\mathrm{M}-3 \mathrm{H}]^{3+}$ ions [36-38]. The determined methylated monosaccharides in glycan structures may be MeMan or MeGal found in $\beta c-H l H$. It is important to note the absence of acid glycans with

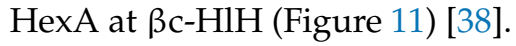
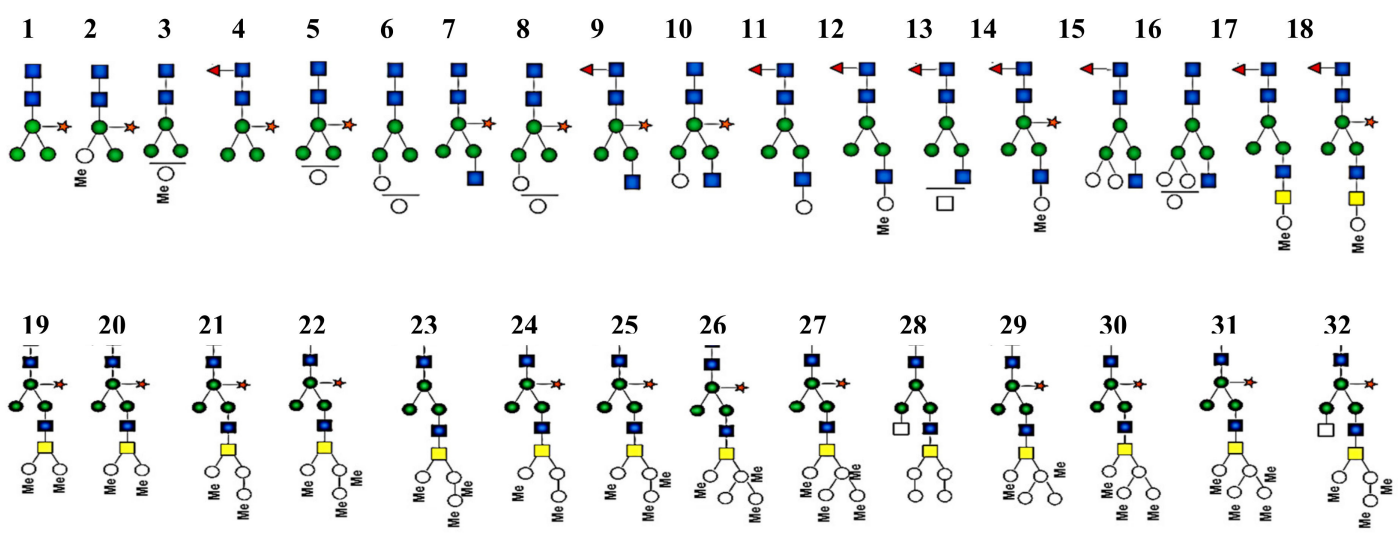

Figure 10. Neutral $\mathrm{N}$-attached glycans from $\beta \mathrm{c}-\mathrm{HlH}$, obtained after treatment with PNGase. Monosaccharides, presented through nomenclature of the consortium of functional glycomics. 
The obtained results from conducted experiments of APTS-labeled $\mathrm{N}$-glycans and CE-MS also confirm the complex structures of $\mathrm{HlH}$ [37]. Similar structures have been published for other molluscan hemocyanins, such as Helix pomatia, Lymnaea stagnalis [16], and Arion lusitanicus [19], suggesting that methylated $\mathrm{N}$-glycans perform an important function in the body.

Important information is presented on the complex structure of some glycopeptides, such as the designated Xyl moiety attached to the Man residue from inside the glycan, as well as the $N$-linked glycosylation site to which the glycan is attached.

The position of the glycans in the hemocyanin is also expressed after mass spectral analysis of some $\beta \mathrm{c}-\mathrm{HlH}$ glycopeptides. An important advantage of analyzing the carbohydrate structure of $\mathrm{HlH}$ is its determined nucleotide sequence, which helps determining the motifs "NXT" and "NXS", and glycosylation of the sites accordingly.

\begin{tabular}{|c|c|c|c|}
\hline 브o & Glycan's structures from $\beta-\mathrm{HIH}$ & $\begin{array}{c}\text { Q-Trap/MS } \\
\text { (m/z) }\end{array}$ & $\begin{array}{l}\text { MALDI- } \\
\text { TOF/MS } \\
(\mathrm{m} / \mathrm{z})\end{array}$ \\
\hline 1 & IICNAC-GICNAC & $\begin{array}{l}{[\mathrm{M}+\mathrm{Na}]^{+}} \\
1065,3\end{array}$ & $\begin{array}{r}{[\mathrm{M}+\mathrm{Na}]^{+}} \\
1065,4\end{array}$ \\
\hline 2 & IcNAC-GICNAC & $\begin{array}{c}{[\mathrm{M}+\mathrm{Na}]^{+}} \\
1079,1\end{array}$ & $\begin{array}{c}{[\mathrm{M}+\mathrm{Na}]^{+}} \\
1079,2\end{array}$ \\
\hline 3 & MeHex+\{ $\left\{\begin{array}{l}\text { Man } \\
\text { Man }\end{array}\right.$ Mar $^{2}$ & \begin{tabular}{|c|}
{$[\mathrm{M}+\mathrm{Na}]^{+}$} \\
1109,2 \\
\end{tabular} & $\begin{array}{l}\mathrm{M}+\mathrm{Na}]^{+} \\
1109,3 \\
\end{array}$ \\
\hline 4 & 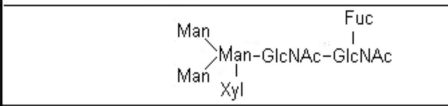 & $\begin{array}{c}{[\mathrm{M}+\mathrm{Na}]^{+}} \\
1211,3\end{array}$ & $\begin{array}{c}{[\mathrm{M}+\mathrm{Na}]^{+}} \\
1211,4\end{array}$ \\
\hline 5 & II-GICNAC-GIcNAc & $\begin{array}{c}{[\mathrm{M}+\mathrm{H}]^{+}} \\
1205,4\end{array}$ & $\begin{array}{c}{[\mathrm{M}+\mathrm{Na}]^{+}} \\
1227,4\end{array}$ \\
\hline 6 & IlcNAc-GIcNAc & $\begin{array}{c}{[\mathrm{M}+\mathrm{H}]^{+}} \\
1235,3 \\
\end{array}$ & $\begin{array}{c}{[\mathrm{M}+\mathrm{Na}]^{+}} \\
1257,4 \\
\end{array}$ \\
\hline 7 & GICNAC-GIcNAc & $\begin{array}{c}{[\mathrm{M}+\mathrm{Na}]^{+}} \\
1268,5\end{array}$ & $\begin{array}{c}{[\mathrm{M}+\mathrm{Na}]^{+}} \\
1268,4\end{array}$ \\
\hline 8 & 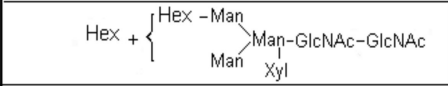 & \begin{tabular}{|l|}
{$[\mathrm{M}+\mathrm{Na}]^{+}$} \\
1367,5
\end{tabular} & $\begin{array}{c}{[\mathrm{M}+\mathrm{Na}]^{+}} \\
1389,4\end{array}$ \\
\hline 9 & $\begin{array}{c}\text { Fuc } \\
\text { IICNAC-GICNAC } \\
\text { GIC }\end{array}$ & $\mid \begin{array}{c}{[\mathrm{M}+\mathrm{Na}]^{+}} \\
1414,3\end{array}$ & $\begin{array}{c}{[\mathrm{M}+\mathrm{Na}]^{+}} \\
1414,4\end{array}$ \\
\hline 10 & 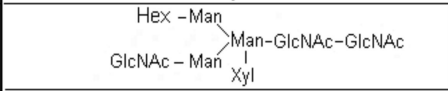 & $\begin{array}{c}{[\mathrm{M}+\mathrm{H}]^{+}} \\
1378,3\end{array}$ & $\begin{array}{c}{[\mathrm{M}+\mathrm{Na}]^{+}} \\
1430,4\end{array}$ \\
\hline 11 & Hex-GlcNAc-Man & $\begin{array}{l}{[\mathrm{M}+\mathrm{H}]^{+}} \\
1422,3\end{array}$ & $\begin{array}{c}{[\mathrm{M}+\mathrm{Na}]^{+}} \\
1444,4\end{array}$ \\
\hline 12 & $\begin{array}{r}\text { Fuc } \\
\text { n-GIcNAc-GIcNAc } \\
\end{array}$ & $\begin{array}{l}\mathrm{M}+\mathrm{Na}]^{+} \\
1458,3\end{array}$ & $\begin{array}{l}{[\mathrm{M}+\mathrm{Na}]^{+}} \\
1458.4\end{array}$ \\
\hline 13 & $H \operatorname{HexNAc}+\left\{\begin{array}{c}\text { Man } \\
\text { GlcNAc-Man }\end{array}\right.$ & $\begin{array}{l}\mathrm{M}+\mathrm{Na}]^{+} \\
1485,4 \\
\end{array}$ & $\begin{array}{c}{[\mathrm{M}+\mathrm{Na}]^{+}} \\
1485,5 \\
\end{array}$ \\
\hline 14 & 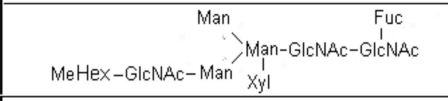 & $\begin{array}{l}{[\mathrm{M}+\mathrm{H}]^{+}} \\
1568,2\end{array}$ & $\begin{array}{c}{[\mathrm{M}+\mathrm{Na}]^{+}} \\
1590,3\end{array}$ \\
\hline 15 & Gex 'Man & $\begin{array}{l}{[\mathrm{M}+\mathrm{Na}]^{+}} \\
1606,5\end{array}$ & $\begin{array}{l}{[\mathrm{M}+\mathrm{Na}]^{+}} \\
1606,6\end{array}$ \\
\hline 16 & 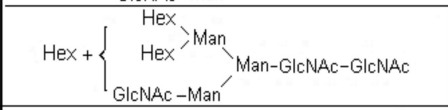 & $\begin{array}{l}{[\mathrm{M}+\mathrm{Na}]^{+}} \\
1622,4\end{array}$ & $\begin{array}{l}{[\mathrm{M}+\mathrm{Na}]^{+}} \\
1622,5\end{array}$ \\
\hline 17 & MeHex-GalNAc-GlcNAc-Man & $\begin{array}{r}{[\mathrm{M}+\mathrm{H}]^{+}} \\
1639,5\end{array}$ & $\begin{array}{c}{[\mathrm{M}+\mathrm{Na}]^{+}} \\
1661,5\end{array}$ \\
\hline 18 & 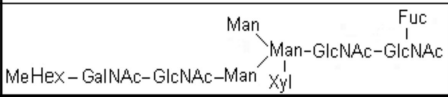 & {$\left[\begin{array}{c}{[\mathrm{M}+2 \mathrm{Na}]^{2+}} \\
908,2\end{array}\right.$} & $\begin{array}{c}{[\mathrm{M}+\mathrm{Na}]^{+}} \\
1793,5\end{array}$ \\
\hline
\end{tabular}

\begin{tabular}{|c|c|c|c|}
\hline 브 & Glycan's structures from $\beta-\mathrm{HIH}$ & $\begin{array}{c}\text { Q-Trap/MS } \\
\text { (m/z) }\end{array}$ & $\begin{array}{c}\text { MALDI- } \\
\text { TOF/MS } \\
(\mathrm{m} / \mathrm{z})\end{array}$ \\
\hline 19 & 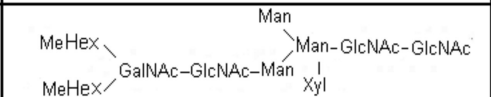 & $\begin{array}{c}{[\mathrm{M}+2 \mathrm{Na}]^{2+}} \\
923,2\end{array}$ & $\begin{array}{c}\mathrm{M}+\mathrm{Na}]^{+} \\
1823,4\end{array}$ \\
\hline 20 & 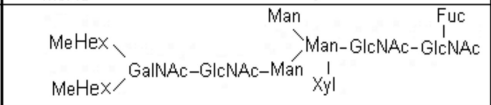 & $\begin{array}{c}{[\mathrm{M}+2 \mathrm{Na}]^{2+}} \\
996,4\end{array}$ & $\begin{array}{c}{[\mathrm{M}+\mathrm{Na}]^{+}} \\
1970,0\end{array}$ \\
\hline 21 & $\begin{array}{l}\text { MeHex } \\
\text { MeHex-Hex }\end{array}$ & $\begin{array}{c}{[\mathrm{M}+2 \mathrm{Na}]^{2+}} \\
1004,3\end{array}$ & $\begin{array}{c}{[\mathrm{M}+\mathrm{Na}]^{+}} \\
1985,4\end{array}$ \\
\hline 22 & 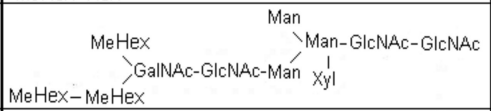 & $\begin{array}{c}{[\mathrm{M}+2 \mathrm{Na}]^{2+}} \\
1011,4\end{array}$ & $\begin{array}{c}{[\mathrm{M}+\mathrm{Na}]^{+}} \\
1999,6\end{array}$ \\
\hline 23 & $\begin{array}{cc}\text { Man } & \text { Fuc } \\
\text { SalNAc-GlcNAc-Mán } & \text { Man-GlcNAc-GlcNAc } \\
\end{array}$ & $\begin{array}{c}{[\mathrm{M}+2 \mathrm{Na}]^{2+}} \\
1018,3\end{array}$ & $\begin{array}{c}{[\mathrm{M}+\mathrm{Na}]^{+}} \\
2013,5\end{array}$ \\
\hline 24 & 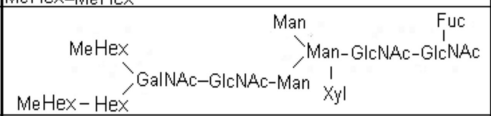 & $\begin{array}{c}{[\mathrm{M}+2 \mathrm{Na}]^{2+}} \\
1077,2\end{array}$ & $\begin{array}{l}{[\mathrm{M}+\mathrm{Na}]^{+}} \\
2131,6\end{array}$ \\
\hline 25 & 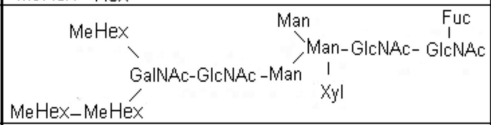 & $\begin{array}{c}{[\mathrm{M}+2 \mathrm{Na}]^{2+}} \\
1084,3\end{array}$ & $\begin{array}{l}{[\mathrm{M}+\mathrm{Na}]^{+}} \\
2145,6\end{array}$ \\
\hline 26 & 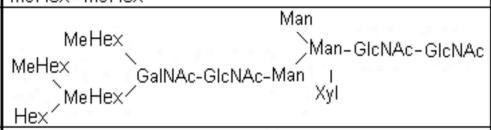 & $\begin{array}{c}{[\mathrm{M}+2 \mathrm{Na}]^{2+}} \\
1092,3\end{array}$ & $\begin{array}{l}{[\mathrm{M}+\mathrm{Na}]^{+}} \\
2161,6\end{array}$ \\
\hline 27 & 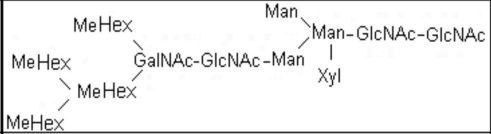 & $\begin{array}{c}{[\mathrm{M}+2 \mathrm{Na}]^{2+}} \\
1099,3\end{array}$ & $\begin{array}{c}{[\mathrm{M}+\mathrm{Na}]^{+}} \\
2175,5\end{array}$ \\
\hline 28 & $\begin{array}{l}\text { Hex-Hex HexNAc-Man } \\
\text { GalNAc-GlcNAc-Man Man-GlcNAc-GlcNAC } \\
\text { Hex-Hex }\end{array}$ & $\begin{array}{l}{[\mathrm{M}+2 \mathrm{Na}]^{2+}} \\
1106,5 \\
\end{array}$ & $\begin{array}{c}{[\mathrm{M}+\mathrm{Na}]^{+}} \\
2190,4\end{array}$ \\
\hline 29 & $\begin{array}{l}\text { Mex } \\
\mathrm{Hex} / \text { MeHex } \\
\mathrm{Hex}\end{array}$ & $\begin{array}{c}{[\mathrm{M}+2 \mathrm{Na}]^{2+}} \\
1158,4\end{array}$ & $\begin{array}{l}{[\mathrm{M}+\mathrm{Na}]^{+}} \\
2293,6\end{array}$ \\
\hline 30 & \begin{tabular}{|l} 
\\
MeHex \\
MeHex \\
Methex
\end{tabular} & $\begin{array}{c}{[\mathrm{M}+2 \mathrm{Na}]^{2+}} \\
1165,4\end{array}$ & $\begin{array}{c}{[\mathrm{M}+\mathrm{Na}]^{+}} \\
2307,6\end{array}$ \\
\hline 31 & $\begin{array}{l}\text { MeHex } \\
\text { MeHex GalNAc-GIcNAc-Man } \\
\text { MeHex } \\
\text { MeHex }\end{array}$ & $\begin{array}{l}{[\mathrm{M}+2 \mathrm{Na}]^{2+}} \\
1172,4\end{array}$ & $\begin{array}{c}{[\mathrm{M}+\mathrm{Na}]^{+}} \\
2321,6\end{array}$ \\
\hline 32 & 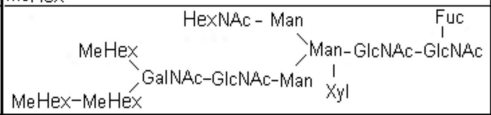 & $\begin{array}{c}{[\mathrm{M}+2 \mathrm{Na}]^{2+}} \\
1185,8\end{array}$ & $\begin{array}{c}{[\mathrm{M}+\mathrm{Na}]} \\
2348,6\end{array}$ \\
\hline
\end{tabular}

Figure 11. Structures of glycans from $\beta-\mathrm{HlH}$, determined through different methods [37]. 
Based on this information, $13 \mathrm{~N}$-binding sites in $\beta \mathrm{c}-\mathrm{HlH}, 14$ in $\alpha \mathrm{D}-\mathrm{HlH}$, and 8 in $\alpha \mathrm{N}-\mathrm{HlH}$ are identified on different positions in their FUs. Only one potential site is located in $\beta c-H l H-e$, two in $\beta c-H l H-a,-f$, and -g, and three $N$-binding sites in $\beta c-H l H-d$ and -h (Figure 11) [39].

\section{Carbohydrate Structure of Hemocyanins from Haliotis tuberculata}

The complex carbohydrate structure of subunit $\mathrm{HtH} 1$ from molluscan hemocyanin Haliotis tuberculata $(\mathrm{HtH})$ is also presented. Preliminary data from MALDI-MS, performed before and after treatment of the glycans from subunit $\mathrm{HtH} 1$ with the specific exoglycosidases $\beta 1-3,4,6-$ galactosidase and $\alpha-1,6$ - and $\alpha-2,3,4$-fucosidase, confirm the complex structure of the glycoprotein. After application of the second approach, 15 new structures of $\mathrm{N}$-linked glycans to $\mathrm{HtH} 1$ were determined by Q-trap tandem mass spectrometry [40].

One complex structure of $\mathrm{HtH} 1$ is presented in Figure 12 with a glycan at $m / z 1002.8[\mathrm{M}+2 \mathrm{Na}]^{2+}$ and structure of $\mathrm{MeHex}_{2} \mathrm{HexMan}_{3} \mathrm{GlcNAc}_{\mathrm{F}} \mathrm{Fuc}_{2}$, including two Fuc and two terminal MeHex residues bound to internal GlcNAc.

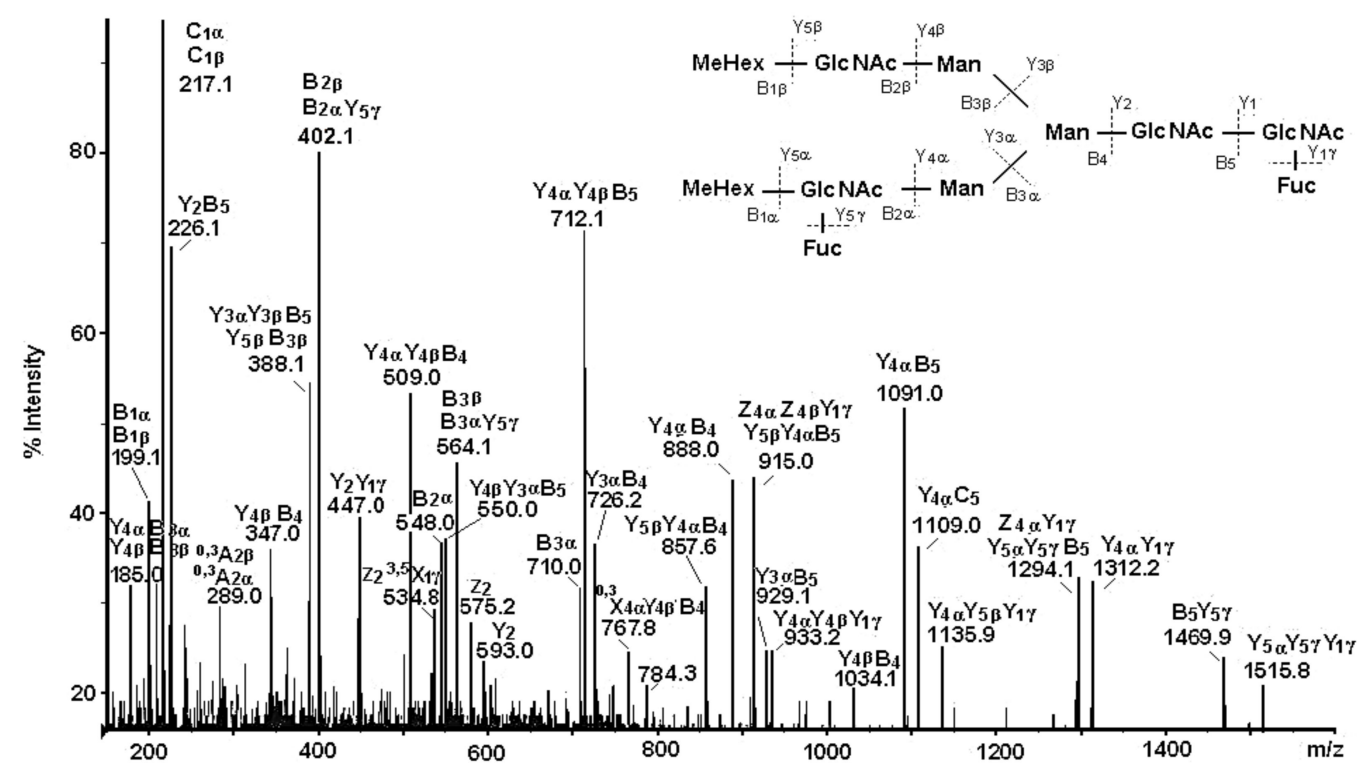

Figure 12. MS/MS spectrum of $\mathrm{HtH} 1$ glycan represented by ion with $m / z 1002.8[\mathrm{M}+2 \mathrm{Na}]^{2+}$ and complex carbohydrate structure [40].

The large set of ions in the MS/MS spectrum determines the structure of the glycan, the positions of two Fuc residues in the said chains, and one bound $\operatorname{Fuc}(\alpha 1-6)$ residue to the pentasaccharide core in the glycan. On the basis of the obtained data, a conclusion about the wide variety of structures of the $15 \mathrm{~N}$-linked glycans of $\mathrm{HtH} 1$ was made (Figure 13).

As a general feature of the structures of glycans 1, 5, 8, 10, 12, 13, 14, and 15, a bound Fuc ( $\alpha 1-6)$ residue to the pentasaccharide nucleus is outlined. Another interesting feature is the structures of glycans 4, 12 and 15 of $\mathrm{HtH} 1$ with MeHex, which is also found in other hemocyanins of the molluscan species.

The advantage of the new methods and approaches developed should be noted, which allows the determination of complex structures of glycans $6,8,9,10,12,13,15$, and 16 in which a novel MeMan [Fuc( $\alpha 1-3)-]$ GlcNAc structural motif is linked to an internal GlcNAc residue.

The discovered modifications in glycan 7 are interesting and complex, where a Xyl residue is attached to carbon-2 (C2) of Man from the core $\mathrm{Man}_{3} \mathrm{GlcNAc}_{2}$ or a Fuc residue is attached to $\mathrm{C} 6$ of GlcNAc. Chemical structure analysis of the oligosaccharides of Todarodes pacificus hemocyanin revealed that the two most abundant sequences HexNAc+Man ${ }_{3} \mathrm{GlcNAc}_{2}$ and HexHex+NAcMan ${ }_{3} \mathrm{GlNAc}_{2}$ accounted for $>95 \%$ of oligosaccharides in all individuals tested [9]. 


\begin{tabular}{|c|c|c|c|c|c|c|c|}
\hline № & Glycon structures from $\mathrm{HtH} 1$ & $\begin{array}{l}\text { Q-Trap } \\
\mathbf{M S}(\mathbf{m} / z)\end{array}$ & $\begin{array}{l}\text { MALDI-TOF } \\
\operatorname{MS}(\mathbb{m} / z)\end{array}$ & № & Glycon structures from HtH1 & $\begin{array}{l}\text { Q-Trap } \\
\mathbf{M S}(\mathbf{m} / \mathbf{z})\end{array}$ & $\begin{array}{l}\text { MALDI-TOF } \\
\text { MS(m/z) }\end{array}$ \\
\hline 1 & 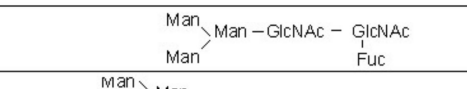 & $\begin{array}{l}{[\mathrm{M}+\mathrm{H}]^{+}} \\
1056.8 \\
\end{array}$ & $\begin{array}{c}{[\mathrm{M}+\mathrm{Na}]^{+}} \\
1079.4 \\
\end{array}$ & 12 & $\begin{array}{l}\text { Man - GICNAC-Man } \\
\text { Me Man- GICNAC-Man ' Man-GICNAC - GICNAC } \\
\text { Fuc }\end{array}$ & $\begin{array}{l}{[\mathrm{M}+2 \mathrm{Na}]^{2+}} \\
923.2\end{array}$ & $\begin{array}{c}{[\mathrm{M}+\mathrm{Na}]^{+}} \\
1823.4\end{array}$ \\
\hline 2 & $\stackrel{\text { Man }^{\prime}>\text { Man }}{\text { Man }^{\prime}}>M$ & $\begin{array}{l}{[\mathrm{M}+\mathrm{H}]^{+}} \\
1235.0\end{array}$ & $\begin{array}{l}|\mathrm{M}+\mathrm{Na}|^{+} \\
1257.4\end{array}$ & \multirow{2}{*}{13} & $\frac{\text { HuC }}{\text { MeMan-GICNAC - Man }}>$ Man-GIcNAC-GIcNAC & \multirow{2}{*}{$\begin{array}{l}{[\mathrm{M}+2 \mathrm{Na}]^{2+}} \\
1002 .{ }^{-}\end{array}$} & \multirow{2}{*}{$\begin{array}{l}{[\mathrm{M}+\mathrm{Na}]^{+}} \\
1983.2\end{array}$} \\
\hline 3 & 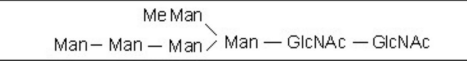 & $\begin{array}{l}{[\mathrm{M}+\mathrm{H}]^{+}} \\
1248.6\end{array}$ & $\begin{array}{c}\mathrm{CM}_{\mathrm{M}+\mathrm{Na}]^{+}} \\
1271.4 \\
\end{array}$ & & $\begin{array}{l}1 \\
\text { Fuc } \\
\end{array}$ & & \\
\hline 4 & $\begin{array}{r}\text { Me Man } \\
\text { MeMan-Man-Man }\end{array}$ & $\begin{array}{l}{[\mathrm{M}+\mathrm{Na}]^{+}} \\
1285.0\end{array}$ & $\begin{array}{l}{[\mathrm{M}+\mathrm{Na}]^{+}} \\
1285.4\end{array}$ & \multirow[t]{2}{*}{14} & $\begin{array}{c}\text { Fuc } \\
\text { Man-GICNAC - Man } \backslash \text { Man-GICNAC - GICNAC }\end{array}$ & \multirow{2}{*}{$\begin{array}{l}{[\mathrm{M}+2 \mathrm{Na}]^{2+}} \\
1062.2\end{array}$} & \multirow{2}{*}{$\begin{array}{l}{[\mathrm{M}+\mathrm{Na}]^{+}} \\
2101.4\end{array}$} \\
\hline 5 & $\begin{array}{l}\text { Man-Man }>\text { Man-GICNAC - GIcNAC } \\
\text { GlcNAc - Man }>\text { Fuc }\end{array}$ & $\begin{array}{r}{[\mathrm{M}+\mathrm{H}]^{+}} \\
1422.0\end{array}$ & $\begin{array}{l}{[\mathrm{M}+\mathrm{Na}]^{+}} \\
1444.4\end{array}$ & & $\begin{array}{l}1 \\
\text { Fuc } \\
\end{array}$ & & \\
\hline 6 & $\begin{array}{l}\text { Man }>\text { Man-GIcNAC-GIcNAC } \\
\text { MeMan-GIcNAC-Man } \\
\text { Fuc } \\
\text { fuc }\end{array}$ & $\begin{array}{l}1422.0 \\
\mathrm{M}+\mathrm{H}]^{+} \\
1436.0\end{array}$ & $\begin{array}{c}{[\mathrm{M}+\mathrm{Na}]^{+}} \\
1458.2\end{array}$ & 15 & 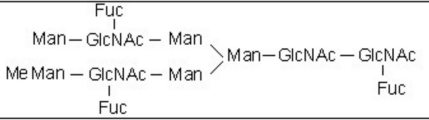 & $\begin{array}{c}{[\mathrm{M}+2 \mathrm{Na}]^{2+}} \\
1069.2\end{array}$ & $\begin{array}{c}{[\mathrm{M}+\mathrm{Na}]^{+}} \\
2115.5\end{array}$ \\
\hline 7 & 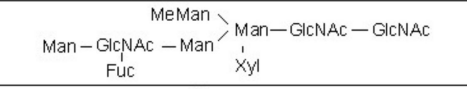 & $\begin{array}{l}{[\mathrm{M}+\mathrm{H}]^{+}} \\
1568.0\end{array}$ & $\begin{array}{l}{[\mathrm{M}+\mathrm{Na}]^{+}} \\
1590.1\end{array}$ & \multirow[t]{2}{*}{16} & $\begin{array}{c}\text { FuC } \\
\text { Me Man-GICNAC - Man } \\
\text { Me Man-GICNAC - Man }>\text { Man-GICNAC - GICNAC }\end{array}$ & \multirow[t]{2}{*}{$\begin{array}{l}{[\mathrm{M}+2 \mathrm{Na}]^{2+}} \\
1076.3\end{array}$} & \multirow[t]{2}{*}{$\begin{array}{l}{[\mathrm{M}+\mathrm{Na}]^{+}} \\
2129.5\end{array}$} \\
\hline 8 & $\begin{array}{r}\text { Man } \\
\text { Me Man - GICNAC - Man }>\text { Man - GlcNAC - GIcNAC } \\
\text { Fuc }\end{array}$ & {$[\mathrm{M}+\mathrm{H}]^{+}$} & {$[\mathrm{M}+\mathrm{Na}]^{+}$} & & $\begin{array}{l}1 \\
\text { Fuc }\end{array}$ & & \\
\hline & Fuc & 1582.0 & 1604.5 & & & & \\
\hline 9 & $\begin{array}{l}\text { Man - Man } \backslash \text { Man-GIcNAC - GICNAC } \\
\text { MeGICNAC - GICNAC - Man } \\
\text { I } \\
\text { Fuc }\end{array}$ & $\begin{array}{l}\mathrm{M}+\mathrm{H}]^{+} \\
1639.0\end{array}$ & $\begin{array}{c}{[\mathrm{M}+\mathrm{Na}]^{+}} \\
1661.2\end{array}$ & & & & \\
\hline 10 & 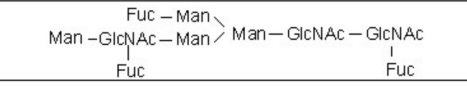 & $\begin{array}{c}{[\mathrm{M}+2 \mathrm{Na}]^{2}} \\
878.9\end{array}$ & $\begin{array}{l}{[\mathrm{M}+\mathrm{Na}]^{+}} \\
1736.5\end{array}$ & & & & \\
\hline 11 & $\begin{array}{c}\text { Man - Man } \\
\text { Me Man-GlcNAC-Man-Man-GlcNAc-GIcNAC } \\
\text { Fuc } \\
\text { Fuc }\end{array}$ & $\begin{array}{c}{[\mathrm{M}+2 \mathrm{Na}]^{2}} \\
902.8\end{array}$ & $\begin{array}{c}|\mathrm{M}+\mathrm{Na}|^{+} \\
1782.4 \\
\end{array}$ & & & & \\
\hline
\end{tabular}

Figure 13. Structure of the glycans isolated from $\mathrm{HtH} 1$

\section{Glycosylated Sites of Hemocyanins from Molluscs}

A general characteristic of the hemocyanins is the potential glycosylation sites in the molecule. The published nucleotide sequences can help us to suggest the features of the carbohydrate structures of the $\mathrm{HlH}, \mathrm{KLH}$, and $\mathrm{HtH} 1$ subunits [25,39].

\subsection{Glycosylation Sites in Helix lucorum Hemocyanins}

The established positions on the active sites in $\mathrm{HlH}$ are different for the $\alpha \mathrm{D}-\mathrm{HlH}$ subunit, where $\alpha \mathrm{D}-\mathrm{HlH}-\mathrm{c}$ has one site, two are found in $\alpha \mathrm{D}-\mathrm{HlH}-\mathrm{d}$ and-e, and three in FUs $\alpha \mathrm{D}-\mathrm{HlH}-\mathrm{a},-\mathrm{g}$, and -h. Partial information about potential binding sites is presented for the $\alpha \mathrm{N}-\mathrm{HlH}$ subunit, because of the indefinite full amino acid sequences, with one site located in FUs $\alpha \mathrm{N}-\mathrm{HlH}-\mathrm{a},-\mathrm{b},-\mathrm{g}$, and $-\mathrm{h}$ and two in $\alpha \mathrm{N}-\mathrm{HlH}-\mathrm{d}$ and $\alpha \mathrm{N}-\mathrm{HlH}-\mathrm{e}$.

In confirmation of the data on the location of the putative sites on the surface of the molecule, the positions of the glycans in the constructed 3D-model of FU $\beta \mathrm{c}-\mathrm{HlH}-\mathrm{g}$ are presented [41] (Figure 14). The presented 3D-model of FU $\beta \mathrm{c}-\mathrm{HlH}$-g is composed of two domains, the active site and one putative $N$-linked glycosylation site at positions 125-127, which are located in/on one of the "central" domains. Another site is located at position 372-374 in the " $\beta$-sandwich" domain with both putative sites exposed to the surface of the molecule. They are mainly concentrated between $\beta 11$ - and $\beta 12$-sheet structures, as reported for the FUs $\beta c-H l H-a,-d,-e$ and -g [39]. Different positions have important roles in the oligomerization of the molecule and the formation of di-decameric forms. $\mathrm{N}$-glycosylation sites located at the C-end of $\mathrm{FU}$ " $\mathrm{h}$ " from $\alpha \mathrm{D}-\mathrm{HlH}$ and $\beta \mathrm{c}-\mathrm{HlH}$ also perform a similar function. As a general characteristic of the three subunits of $\mathrm{HlH}$, a potential glycosylation site in the loop between the $\alpha 16$-helical and $\beta 11$-sheet structures of the $\beta$-sandwich domain can be noted. Another feature of almost all molluscan hemocyanins is the absence of a potential $N$-linked glycosylation site in FU " $\mathrm{c}$ ". This information is confirmed for both $\beta \mathrm{c}-\mathrm{HlH}$ and $\alpha \mathrm{N}-\mathrm{HlH}$ subunits with $\mathrm{N}$ - glycosylation sites also not found for FU-s $\beta c-H l H-b, \alpha D-H l H-b, \alpha D-H l H-f$, and $\alpha \mathrm{N}-\mathrm{HlH}-\mathrm{f}$. 


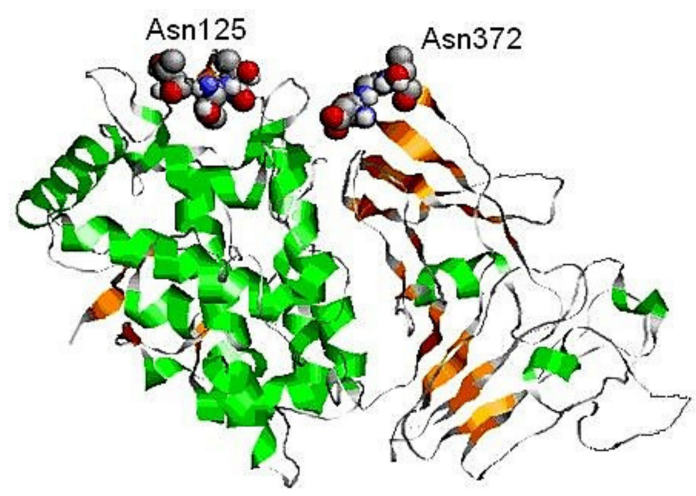

Figure 14. 3D-model of FU $\beta \mathrm{c}-\mathrm{HlH}-\mathrm{g}$, built through the Swiss PDB viewer program and compared with the Octopus dofleini (OdH-g) FU model "g" [41]. Two possible glycosylation sites, to Asn125 and Asn245 residue, are indicated [41].

A similar motif, -Asn-Pro-Thr-, is found in FUs $\beta c-H l H-g$ and $\alpha \mathrm{N}-\mathrm{HlH}-\mathrm{g}$, but glycan binding is blocked by a Pro residue.

This conclusion is valid for all molluscan hemocyanins, but not for the FU $\alpha \mathrm{D}-\mathrm{HlH}$ with one putative glycosylation site at position 331-333 (-AsnAspThr-). This site corresponds to the site of position 143 (-AsnThrSer-), determined by the nucleotide sequence of $\mathrm{RvH}-\mathrm{c}$, which was further demonstrated by the orcinol/ $\mathrm{H}_{2} \mathrm{SO}_{4}$ assay [31]. The location of two glycans on the surface of the 3D-model of $\beta \mathrm{c}-\mathrm{HlH}$-g bonded to the glycosylation sites Asn125 and Asn245 corresponds to the published crystallographic structures of the Odh-g and RtH2-e FUs [42,43].

The nucleotide sequences of $\mathrm{HtH} 1$ and $\mathrm{HtH} 2$ subunits are also known [24,44], and were applied to construct 3D-models of eight FUs in which glycans are located on the surface of the molecule (Figure 15). Two models deserve special attention: one is $\mathrm{FU} \mathrm{HtH1-c,} \mathrm{in} \mathrm{which} \mathrm{a} \mathrm{potential} \mathrm{glycosylation}$ site is absent, and $\mathrm{HtH} 1-\mathrm{h}$, where one of the two presented glycans is exposed on the surface of FU HtH1-h [40].
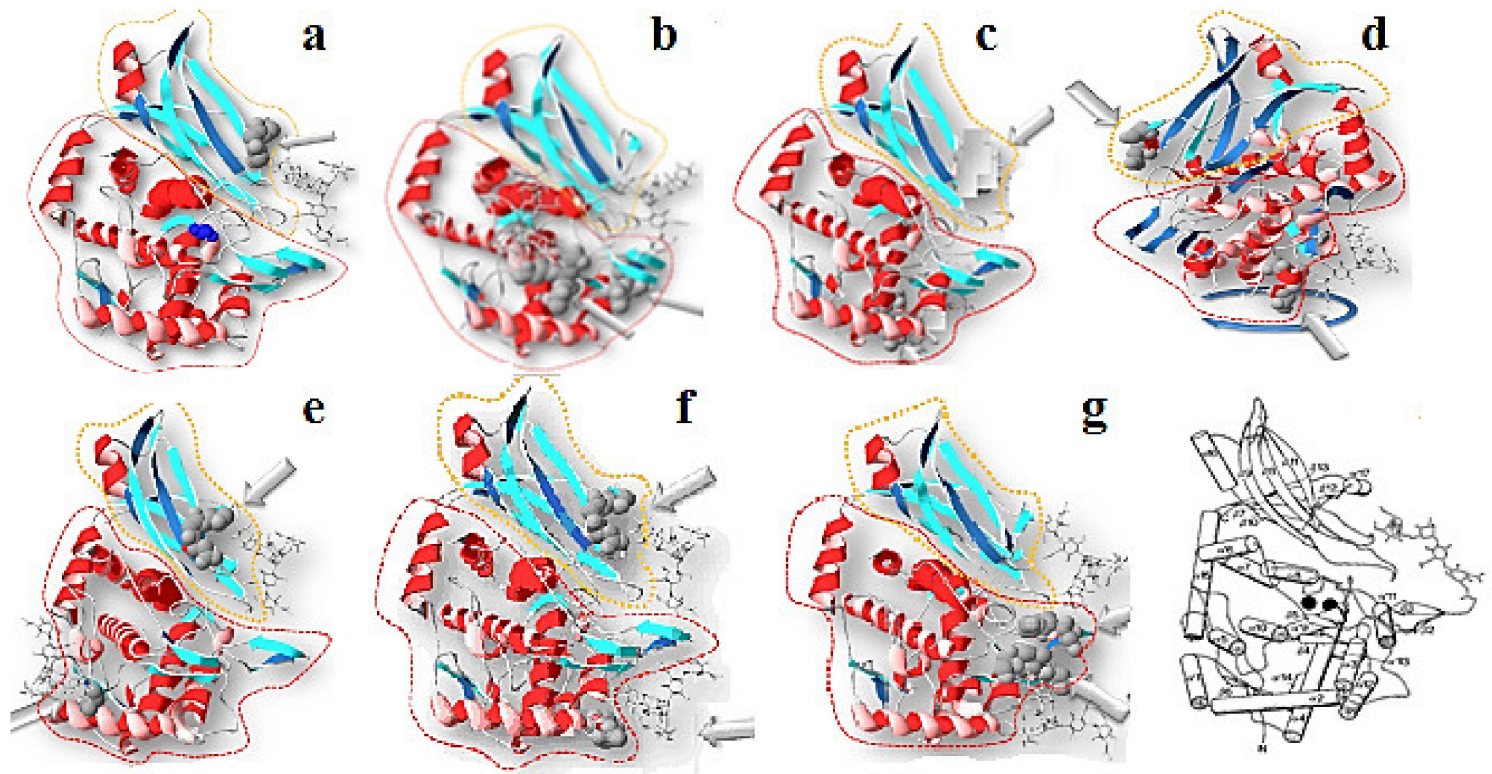

Figure 15. 3D-models of FU from «a" to "g" of HtH1 and potential N-linked sites, depicted on the basis of the structure of OdH-g. $\beta$-sandwich domain (yellow); $\alpha$-nucleus (red); $N$-glycolised site (grey). The glycans are marked with arrows [40]. 
Based on the presented data, an important role for this glycan has been suggested, which probably impedes the re-association of dissociated $\mathrm{HtH} 1$ subunits that do not fibrillate into di-decamers or larger aggregates as observed in some molluscan hemocyanin carbohydrate structures. The new information on the structure of hemocyanin from the garden snail Helix lucorum and Haliotis tuberculata is that they have an area of glycoproteins with predominantly methylated carbohydrate structures, which do not include acidic glycans.

The full characteristics of the complex oligosaccharide structure of hemocyanins from Molluscs are presented after identifying the connecting sites for the glycans to the polypeptide chains of $\mathrm{RvH}$. The absence of information for the amino acid sequence (AAS) of RvH makes the determination of the glycosylation sites difficult. However, this is presented after comparative analysis of drawn results from different applied methods and approaches:

- Edman degradation of glycopeptides;

- Analysis of the peptides after de-glycosylation with specific glycosidases;

- Separation of glycopeptides on the columns and determination of AAS after MS/MS analyses.

$N$ - linked glycosylation sites have been determined in isolated glycopeptides from FUs and subunits of RvH1 using a new method, including labelling of the $N$-linking sites, followed by treatment of the glycopeptides with PNGase F enzyme in buffer containing $50 \% \mathrm{H}_{2}{ }^{18} \mathrm{O}[26,29,33]$.

\subsection{Glycosylation Sites in $\mathrm{RvH}$}

\subsubsection{Glycosylation Sites in RvH Determined by nano-ESI-MS and Q-trap-LC/MS/MS Systems}

The information provided on the glycosylated structure of $\mathrm{RvH}$ has also been confirmed after the determination of glycosylation sites with the development of a new method of analysis of the separated glycans from the polypeptide chain to which the first $N$-linked HexNAc residue remains. An important advantage of the method is fragmentation of the peptide chain by nano-ESI-MS and Q-trap-LC/MS/MS systems, which takes place in the absence of glycans in the cuvette [33].

There are two possible glycosylation sites in the eluted $31.24 \mathrm{~min}$ glycopeptide with AAS MGQYGNXSTNNTR. After triple quadrupole scanning, only one site was shown to be $N$-glycosylated (-NXS-). A drawback of the method is the insufficient information to demonstrate the glycosylation sites of all tested glycopeptides. This problem is solved after applying a new approach that involves MS/MS analyses of nano-LC-ESI-MS/MS triple charged ${ }^{18} \mathrm{O}$-labeled peptides and proof of the glycosylation site.

\subsubsection{Glycosylation Sites in $\mathrm{RvH}$ Determined After ${ }^{18} \mathrm{O}$-Labelling of Peptides}

An additional characteristic of the glycosylation sites in $\mathrm{RvH}$ is presented by applying a new approach after separation of the $N$-glycans from the protein by glycosidase PNGase F and marking of the glycosylation sites of $\mathrm{RvH} 1$ in buffer with $50 \% \mathrm{H}_{2} \mathrm{O}$. The glycosylation sites show a difference of 2 Da between $\mathrm{m} / \mathrm{z}$ of the ${ }^{18} \mathrm{O}$-labeled and unlabeled ions of the MS/MS spectra [33].

This new method is very sensitive and suitable for the analysis and the recognition of glycosylation sites in other glycoproteins, but the presented limited amount of data from the MS/MS spectrum does not allow for de novo analysis to determine the AAS of glycopeptides. This is achieved by a nano-LC-ESI-Q-trap system where, at slow fragmentation over time (TOF) of ${ }^{18} \mathrm{O}-$ labeled peptides, very low ions are detected in the MS spectra (Figure 16).

The $y$-ions and the labeled b3 with $m / z 316.1050[\mathrm{M}+\mathrm{H}]^{+}$in the TDF-MS spectrum of the ${ }^{18} \mathrm{O}$-marked peptide with $m / z 966.0[\mathrm{M}-2 \mathrm{H}]^{2+}$ AAS with one $N$-linked glycosylation site -DLT- was determined [33]. Results from the advantage of the chosen method for detecting ${ }^{18} \mathrm{O}$-labeled glycopeptides in biological solution are presented in Table 2. Preliminary ion scanning at $204 \mathrm{~m} / \mathrm{z}$ of the 23-min elution fraction showed the most intensive ion with $\mathrm{m} / \mathrm{z} 973[\mathrm{M}+2 \mathrm{H}]^{2+}$, which represented a glycopeptide with Mw 1943.6 Da $([972.3 \times 2]-1=1943.6)($ Figure 17A,B) [33]. 


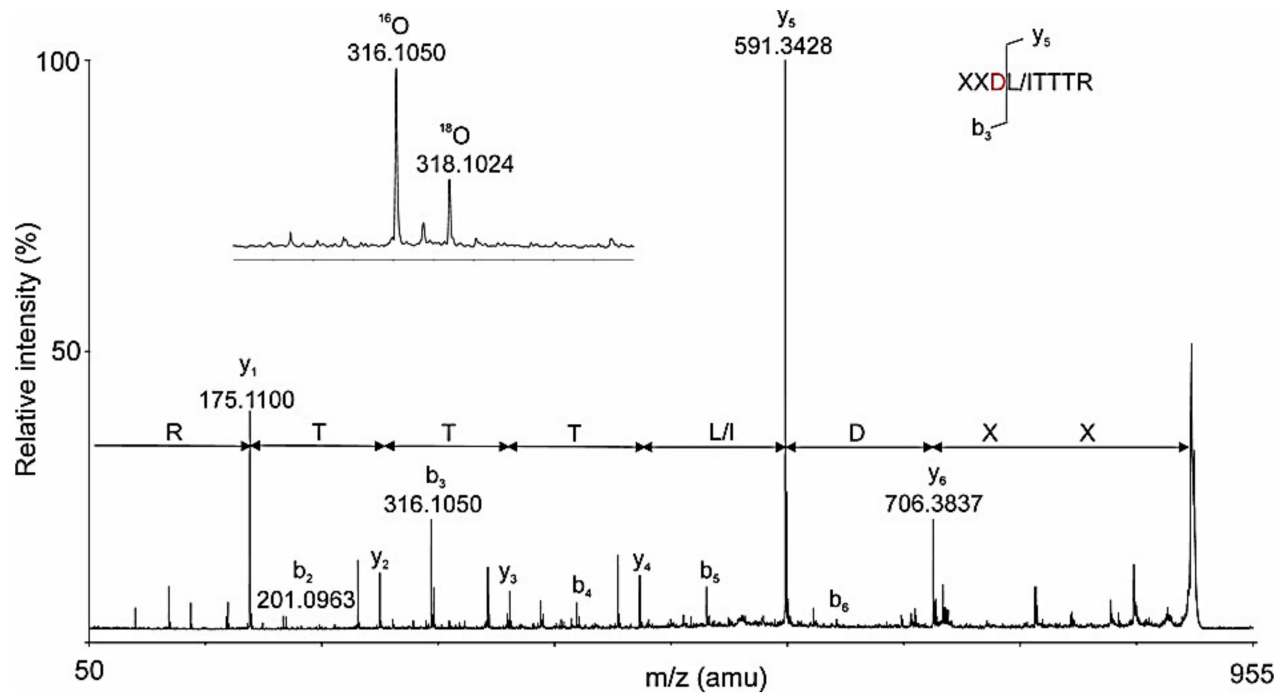

Figure 16. TOF spectrum of ${ }^{18} \mathrm{O}$-labeled peptide, presented from an ion with $m / z 966[\mathrm{M}-2 \mathrm{H}]^{2+}$; collision energy $28 \mathrm{eV}$ and TDF time $8 \mathrm{~ms}$. B) The labeled ion $\mathrm{b}_{3}$ with $\mathrm{m} / \mathrm{z} 316.1050$ is depicted on the figure.

Table 2. AAS and carbohydrate structures of glycopeptides from $\mathrm{RvH}$ analyzed by ESI-MS, Q-Trap-LC/MS/MS and Q-Trap system. X is unknown IF [28,29,33].

\begin{tabular}{|c|c|c|c|}
\hline \multicolumn{2}{|c|}{ Glycopeptides } & Glycans & \multirow[t]{2}{*}{ Mass/Charge } \\
\hline \multicolumn{3}{|r|}{$C E$} & \\
\hline 1 & XVYSVNGTLLGAHVLGSR & $\begin{array}{c}\text { Man3GlcNAc2 } \\
\text { HexA HexNAc2 Fuc2 Man3GlcNAc2 }\end{array}$ & $\begin{array}{r}941[\mathrm{M}+3 \mathrm{H}]^{3+} \\
1233[\mathrm{M}+3 \mathrm{H}]^{3+}\end{array}$ \\
\hline 2 & X-XFSWVDGHNTSR & $\begin{array}{c}\text { GlcNAcMan3GlcNAc2 } \\
\text { FucMan3GlcNAc2 } \\
\text { Man3GlcNAc2 }\end{array}$ & $\begin{array}{l}1168[\mathrm{M}+3 \mathrm{H}]^{3+} \\
1149[\mathrm{M}+3 \mathrm{H}]^{3+} \\
1104[\mathrm{M}+3 \mathrm{H}]^{3+}\end{array}$ \\
\hline 3 & FQNDTSLDGYQAVAEFHGLPAK & FucMan3GlcNAc2 & $1153[\mathrm{M}+3 \mathrm{H}]^{3+}$ \\
\hline 4 & FQNDTSLDGFQAVAEFHGLPPK & GlcNAcMan3GlcNAc2 & $1010[\mathrm{M}+4 \mathrm{H}]^{4+}$ \\
\hline 5 & LHSYSGSYLNASLLHX-X & Man3GlcNAc2 & $968[\mathrm{M}+2 \mathrm{H}]^{2+}$ \\
\hline 6 & XNGTELSPR/XNASELSPR & Hex5Man3GlcNAc2 & $1373[\mathrm{M}+2 \mathrm{H}]^{2+}$ \\
\hline \multicolumn{4}{|c|}{ ESI-MS } \\
\hline 7 & [QK]AENLTTTR & FucMan3GlcNAc2 & $1036[\mathrm{M}+2 \mathrm{H}]^{2+}$ \\
\hline 8 & AENLTTTR & Fuc Man3GlcNAc2 & $972[\mathrm{M}+2 \mathrm{H}]^{2+}$ \\
\hline 9 & HHGHV[...K...N...]R & Fuc Man3GlcNAc2 & $1396[\mathrm{M}+2 \mathrm{H}]^{2+}$ \\
\hline 10 & FSWVDGHNTSR & Man3GlcNAc2 & $1099[\mathrm{M}+2 \mathrm{H}]^{2+}$ \\
\hline 11 & YE[IL]HAVNGST[IL]AA[IL] & Hex3Man3GlcNAc2 & $1339[\mathrm{M}+2 \mathrm{H}]^{2+}$ \\
\hline 12 & YE[IL]HAVNGST[IL]AA[IL] & Hex3Man3GlcNAc2 & $1419[\mathrm{M}+2 \mathrm{H}]^{2+}$ \\
\hline \multicolumn{4}{|c|}{$Q$ trap-LC/MS/MS } \\
\hline 13 & MGQYGDLSTNNTR & Hex Man3HexNAc2 & $837.9[\mathrm{M}+2 \mathrm{H}]^{3+}$ \\
\hline 14 & SVNGTLLGSQILGKPY & Fuc Man3GlcNAc2 & $896[\mathrm{M}+3 \mathrm{H}]^{3+}$ \\
\hline 15 & FSWVDGHNTSR & Man3GlcNAc2 & $1099[\mathrm{M}+2 \mathrm{H}]^{2+}$ \\
\hline 16 & AENITTTR & Fuc Man3GlcNAc2 & $972[\mathrm{M}+2 \mathrm{H}]^{2+}$ \\
\hline 17 & FANATSIDGPNA & SO4 MeHexAMeHexNAc2Man3GlcNAc2 & $2786[\mathrm{M}+\mathrm{H}]^{+}$ \\
\hline 18 & EMLTLNGTNLA & MeHex2AHexNAc2Man3GlcNAc2 & $2846[\mathrm{M}+\mathrm{H}]^{+}$ \\
\hline 19 & IHSYSGSYINASLLHGPSII & MeManMan2GlcNAc2 & $2848[\mathrm{M}+\mathrm{H}]^{+}$ \\
\hline
\end{tabular}




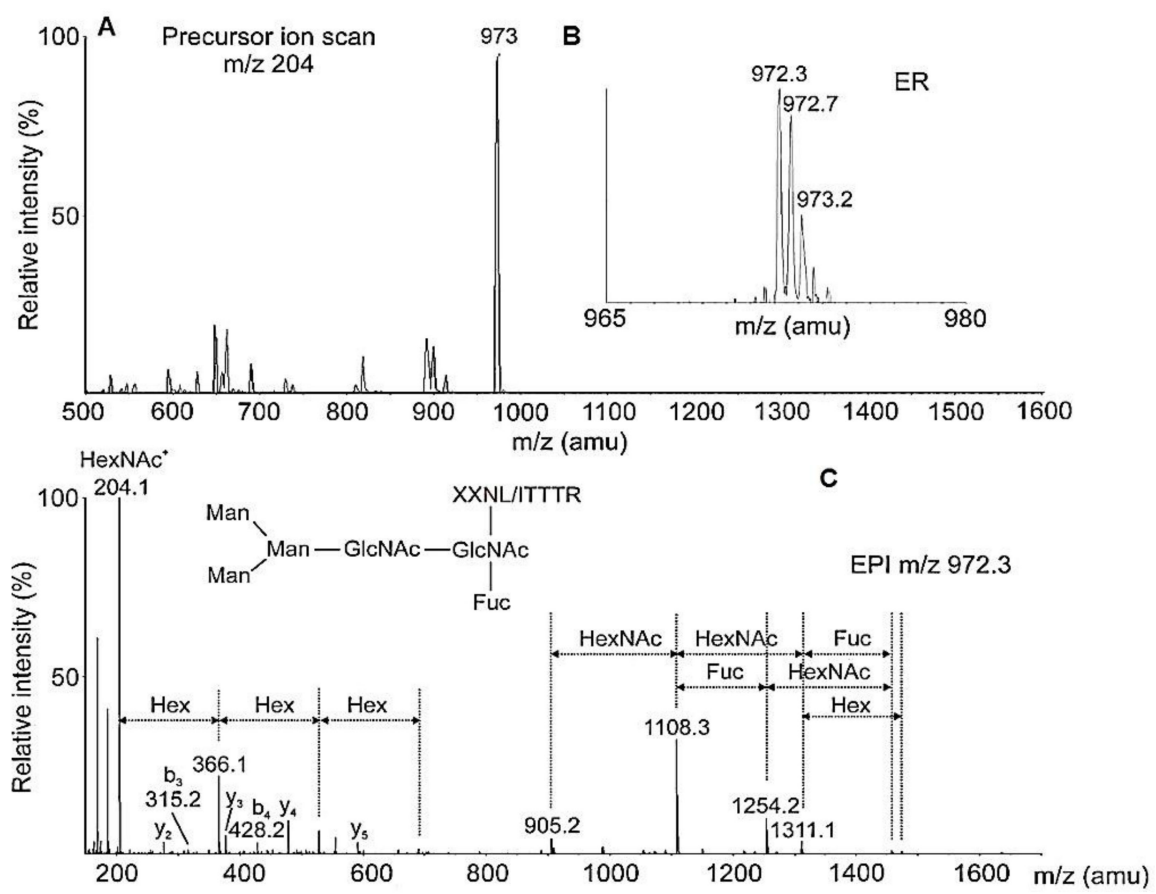

Figure 17. (A) Ion scanning of 23-min eluted fraction. (B) ER scanning of the intensive ion; (C) CEPI scanning of fragmenting ions. Increase of the mass of ion b3 with $1 \mathrm{Da}$ in EPI spectra is compared to the MS/MS of the labeled peptides [33].

Analysis of the ion with $m / z 905.2[\mathrm{M}+\mathrm{H}]^{+}$(a peptide without glycan, Figure 17C) from the MS/MS spectrum proves that one glycan FucMan ${ }_{3} \mathrm{GlCNAc}_{2}$ is attached to the (-NI/LT-) site of the glycopeptide (Table 2). Mass spectra report a difference of $1 \mathrm{Da}$ between the values obtained for a peptide after glycan release with PNGase F and those of ${ }^{18} \mathrm{O}$-labeled ions. The difference reported is evidence of a glycosylation site represented by a group of $[\mathrm{M}+\mathrm{H}]^{+}$ions resulting from the sequential fragmentation of the bound peptide with GlcNAc [33].

\subsubsection{Glycosylation Sites in RvH, Determined After Fragmentation of the Genome}

The positions of glycosylation sites are also demonstrated by the nucleotide sequences of hemocyanin of Haliotis tuberculata, Aplysia californica, Nucula nucleus and Nautilus pompilius $[7,22,24,25,44,45]$, and two fragments of the $\mathrm{RvH}$ genome that partially encode FU-b and FU-c [31]. The negative Orcinol/ $\mathrm{H}_{2} \mathrm{SO}_{4}$ test provides information on the absence of an $\mathrm{N}$-linked site in $\mathrm{RvH}-\mathrm{b}$, confirmed by the obtained 316 amino acid residues (AARs) of RvH-b, as the positive test for sugars corresponds to one $N$-linked site (-Asp-Thr-Ser-) at the 143rd position identified in the nucleotide sequence of RvH-c.

Data obtained from MS/MS analysis of the glycopeptide with $\mathrm{m} / \mathrm{z} 1099.19[\mathrm{M}-2 \mathrm{H}]^{2+}$ (Table 2, № 10) for site AAS (FSGEVDGHNTSR) were corrected by nucleotide sequence. It is known that the Gly residue is not always reflected in the MS/MS spectrum. This was confirmed by the nucleotide analysis of the glycopeptide, where the Trp residue is replaced by -GlyGlu-. The information obtained is consistent with the published putative $\mathrm{N}$-linked glycosylation sites for the FUs $\mathrm{HtH} 2-\mathrm{c}$, OdH-c, and $\mathrm{NpH}-\mathrm{c}$ (Figure 18) and serves as a basis for determination of other RvH characteristics. 

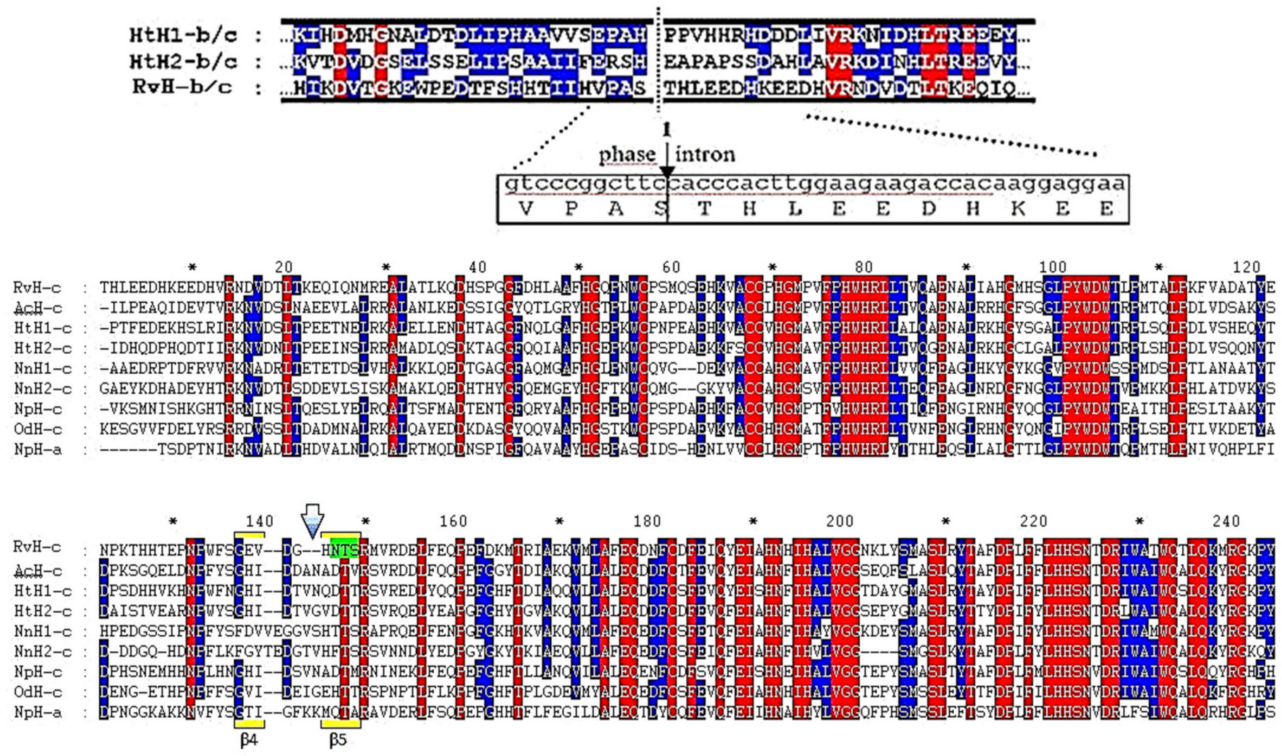

Figure 18. Comparative analysis of the AAS of RvH-c with FUs from other hemocyanins. Conservative sites of the AAS (in blue and red) and N-linked glycosylation site of RvH-c (in green) [31].

The results of the constructed 3D-model of RvH-c represent the located glycans on the surface of the molecule (Figure 19) [31], which is confirmed by the crystallographic structure of hemocyanin FUs of Todarodes pacificus (Figure 1) [9]. The location of $N$-linked glycosylation sites in molluscan hemocyanins is most commonly observed between $\beta 11$ - and $\beta 12$-sheet structures in the $\beta$-sandwich domain of the FUs [25]. For the OdH-d and NpH-d FUs, these positions are similar, but for OdH-g and $\mathrm{NpH}$-g they differ, which is related to the influence of the formed $\mathrm{N}$-glycan site of the opposite FU OdH-g. One site in NpH-g located at the same position, but with no bound glycan, has been demonstrated [22].

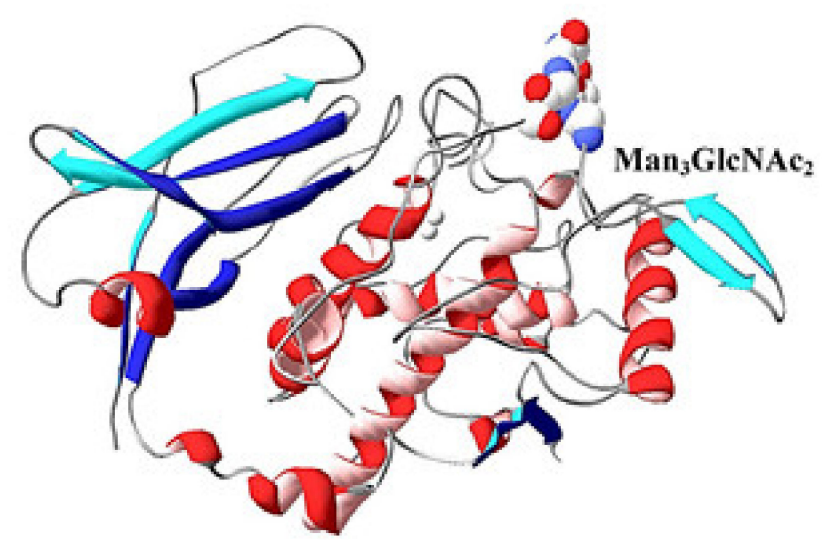

Figure 19. 3D-model of FU RvH-c, depicted on the basis of the structure of the hemocyanin from Octopus dofleini [41]. Glycan, attached to the polypeptide chain of FU-c [31].

The crystal structure of Todarodes pacificus hemocyanin revealed $N$-linked glycosylation at five of seven possible sites, including Asn387 for FU-a, Asn806 for FU-b, Asn1498 and Asn1636 for FU-d, and Asn2472 for FU-e. Four of these sites are located at identical positions, however, FU-d possesses an additional glycan (Figure 20) [9].

The oligosaccharides were all located on the surface of the wall and formed carbohydrate clusters. The carbohydrates conjugated at Asn387 and Asn806 of protomer A (hereafter, glycan-387 A and glycan-806 A), and formed a cluster with glycan 1498 which was located at the interface among three 
protomers, i.e., protomers A, I, and J. Furthermore, this site is located at the interface between two plate-like protomer-dimers.

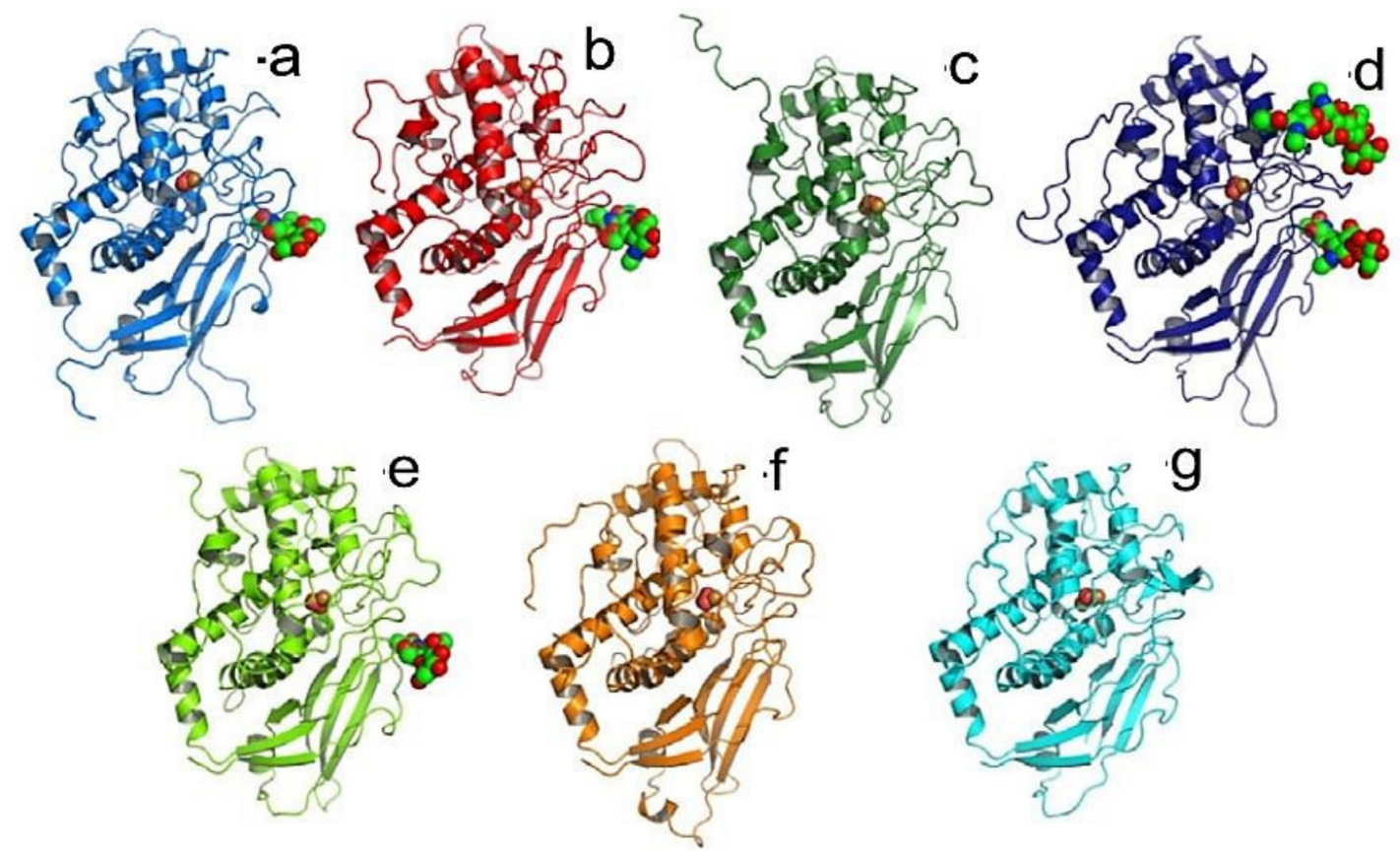

Figure 20. N-linked glycosylation sites of functional units of Todarodes pacificus hemocyanin [9].

Molluscan hemocyanins are oligomeric glycoproteins with complex dodecameric quaternary structures and heterogeneous glycosylation patterns, primarily consisting of mannose-rich $N$-glycans, which contribute to their structural stability and immunomodulatory properties in mammals [46]. The enzyme-catalyzed N-deglycosylation of Concholepas concholepas [47], Fissurella latimarginata [2], and KLH disrupts their quaternary structure and impairs their immunogenic effects. Biochemical analyses confirm the importance of glycans by showing that deglycosylation does not alter the secondary structure of hemocyanin, but alters their re-folding mechanism and dodecameric structure.

\section{Conclusions and Future Direction}

The data provide new information on the carbohydrate structures of oxygen-binding glycoproteins, 'hemocyanins', with two copper atoms in the active site determined by a combination of new methods and techniques. Complex carbohydrate structures have a fucosylated pentsaccharide core and a high degree of methylation.

It is important to note that, along with the common structures, all molluscan hemocyanins stand out with specific glycan structures. Of great interest are the first discovered acid glycans in RvH1 and RvH2, where at two positions from the internal Fuc residue, HexNAc and HexA is bound. The novel MeHex [Fuc ( $\alpha 1-3)$ ] GlcNAc structural motif has also been demonstrated in HtH1 glycans, which is composed of one or two MeHex and ( $\alpha 1-3)$ Fuc bound to internal GlcNAc and an additional Xyl residue.

One of the main characteristics of hemocyanins from the snails Helix lucorum, Helix pomatia, Lymnaea stagnalis, and Arion lusitanicus is the proven predominantly methylated glycan structures of 3-O-methyl-D-mannose and 3-O-methyl-D-galactose. Similar structures have been published for other molluscan hemocyanins, suggesting that methylated $N$-glycans perform an important function in the body.

Comparative analyses of the primary structures of $\mathrm{HtH} 1, \beta c-\mathrm{HlH}$, and $\mathrm{RvH}$ present a high degree of homology to the putative $N$-linked glycosylation sites located on the surface of the FUs. The position of the glycans on the surface of the molecule was also proven by the constructed 3D models of 
$\beta \mathrm{c}-\mathrm{HlH}-\mathrm{g}, \mathrm{RvH}-\mathrm{c}$, as well as the eight $\mathrm{FUs}$ of $\mathrm{HtH1}$, which correspond to the represented positions of the crystallographic structures of OdH-g and RtH2-e [42,43].

The obtained data from these studies provide new information on the carbohydrate structures of molluscan hemocyanins combining typical structural characteristics of various higher organisms (mammals, plants, insects, nematodes and trematodes). This explains the scientists' interest in these glycoproteins, which are a suitable target for determining the effect of glycans on the structure, properties and function of glycoproteins.

Author Contributions: P.D. conceptualized this study, A.D. (Aleksandar Dolashki) and A.D. (Asya Daskalova) performed the literature search and drafted the manuscript, and W.V. edited and provided critical revisions to the finalized review. All authors have read and agreed to the published version of the review.

Funding: This work was supported by the Bulgarian Ministry of Education and Science (Grant D01-217/30.11.2018) under the National Research Programme "Innovative Low-Toxic Bioactive Systems for Precision Medicine (BioActiveMed)" approved by DCM\#658/14.09.2018 and with the support of a project under contract No.DN 01/14 of 19.12.2016, funded by the Scientific Research Fund of the Ministry of Education and Science in the Republic of Bulgaria.

Conflicts of Interest: The authors declare no conflict of interest.

\section{References}

1. Reily, C.; Stewart, T.J.; Renfrow, M.B.; Novak, J. Glycosylation in health and disease. Nat. Rev. Nephrol. 2019, 15, 346-366. [CrossRef] [PubMed]

2. Arancibia, S.; Espinoza, C.; Salazar, F.; Del Campo, M.; Tampe, R.; Zhong, T.Y.; De Ioannes, P.; Moltedo, B.; Ferreira, J.; Lavelle, E.C.; et al. A novel immunomodulatory hemocyanin from the limpet Fissurella latimarginata promotes potent anti-tumor activity in melanoma. PLoS ONE 2014, 9, e87240. [CrossRef] [PubMed]

3. Ayyagari, S.V.; Sreerama, K. Spectroscopic Studies on the Conformational Stability of Hemocyanin of Pila virens (Lamarck, 1822) in the Presence of Temperature and Detergents. Proc. Zool. Soc. 2019, 73, 302-311. [CrossRef]

4. Ulagesan, S.; Kim, H.J. Antibacterial and Antifungal Activities of Proteins Extracted from Seven Different Snails. Appl. Sci. 2018, 8, 1362. [CrossRef]

5. Mendoza-Porras, O.; Kamath, S.; Harris, J.O.; Colgrave, M.L.; Huerlimann, R.; Lopata, A.L.; Wade, N.M. Resolving hemocyanin isoform complexity in haemolymph of black tiger shrimp Penaeus monodon-implications in aquaculture, medicine and food safety. J. Proteom. 2020, 218, 103689. [CrossRef] [PubMed]

6. Zhang, Z.; Wang, F.; Chen, C.; Zheng, Z.; Aweya, J.J.; Zhang, Y. Glycosylation of hemocyanin in Litopenaeus vannameiis an antibacterial response feature. Immunol. Lett. 2017, 192, 42-47. [CrossRef]

7. Gatsogiannis, C.; Markl, J. Keyhole limpet hemocyanin: $9 \AA$ CryoEM structure and molecular model of the KLH1 didecamer reveal the interfaces and intricate topology of the 160 functional units. J. Mol. Biol. 2009, 385, 963-983. [CrossRef]

8. Tanaka, Y.; Kato, S.; Stabrin, M.; Raunser, S.; Matsui, T.; Gatsogiannis, C. Cryo-EM reveals the asymmetric assembly of squid hemocyanin. IUCrJ 2019, 6, 426-437. [CrossRef]

9. Gai, Z.; Matsuno, A.; Kato, K.; Kato, S.; Khan, M.R.I.; Shimizu, T.; Yoshioka, T.; Kato, Y.; Kishimura, H.; Kanno, G.; et al. Crystal Structure of the 3.8-MDa Respiratory Supermolecule Hemocyanin at 3.0A Resolution. Structure 2015, 23, 2204-2212. [CrossRef]

10. Lommerse, J.P.M.; Thomas-Oates, J.E.; Gielens, C.; Préaux, G.; Kamerling, J.P.; Vliegenthart, J.F.G. Primary Structure of 21 Novel Monoantennary and Diantennary N-Linked Carbohydrate Chains from $\alpha$ D-Hemocyanin of Helix pomatia. Eur. J. Biochem. 1997, 249, 195-222. [CrossRef]

11. Gielens, C.; Idakieva, K.; Van Den Bergh, V.; Siddiqui, N.I.; Parvanova, K.; Compernolle, F. Mass spectral evidence for $\mathrm{N}$-glycans with branching on fucose in a molluscan hemocyanin. Biochem. Biophys. Res. Commun. 2005, 331, 562-570. [CrossRef]

12. Gutternigg, M.; Bürgmayr, S.; Pöltl, G.; Rudolf, J.; Staudacher, E. Neutral N-glycan patterns of the gastropods Limax maximus, Cepaea hortensis, Planorbarius corneus, Arianta arbustorum and Achatina fulica. Glycoconj. J. 2007, 24, 475-489. [CrossRef] 
13. Wuhrer, M.; Robijn, M.L.; Koeleman, C.A.; Balog, C.I.; Geyer, R.; Deelder, A.M.; Hokke, C.H. A novel $\mathrm{Gal}(\beta 1-4) \mathrm{Gal}(\beta 1-4) \mathrm{Fuc}(\alpha 1-6)$-core modification attached to the proximal N-acetylglucosamine of keyhole limpet haemocyanin (KLH) N-glycans. Biochem. J. 2004, 378, 625-632. [CrossRef] [PubMed]

14. Kurokawa, T.; Wuhrer, M.; Lochnit, G.; Geyer, H.; Markl, J.; Geyer, R. Hemocyanin from the keyhole limpet Megathura crenulata (KLH) carries a novel type of N-glycans with Gal(beta1-6)Man-motifs. Eur. J. Biochem. 2002, 269, 5459-5473. [CrossRef]

15. Eckmair, B.; Jin, C.; Abed-Navandi, D.; Paschinger, K. Multistep Fractionation and Mass Spectrometry Reveal Zwitterionic and Anionic Modifications of the $N$ - and O-glycans of a Marine Snail. Mol. Cell. Proteom. 2016, 15, 573-597. [CrossRef] [PubMed]

16. Hall, R.L.; Wood, E.J.; Kamberling, J.P.; Gerwig, G.J.; Vliegenthart, F.G. 3-O-methyl sugars as constituents of glycoproteins. Identification of 3-O-methylgalactose and 3-O-methylmannose in pulmonate gastropod haemocyanins. Biochem. J. 1977, 165, 173-176. [CrossRef]

17. Wuhrer, M.; Dennis, R.D.; Doenhoff, M.J.; Geyer, R. A fucose-containing epitope is shared by keyhole limpet haemocyanin and Schistosoma mansoni glycosphingolipids. Mol. Biochem. Parasitol. 2000, 110, $237-246$. [CrossRef]

18. Gielens, C.; De Geest, N.; Compernolle, F.; Préaux, G. Glycosylation sites of hemocyanins of Helix pomatia and Sepia officinalis. Micron 2004, 35, 99-100. [CrossRef] [PubMed]

19. Gutternigg, M.; Ahrer, K.; Grabher-Meier, H.; Bürgmayr, S.; Staudacher, E. Neutral N-glycans of the gastropod Arion lusitanicus. Eur. J. Biochem. 2004, 271, 1348-1356. [CrossRef]

20. Stoeva, S.; Idakieva, K.; Betzel, C.; Genov, N.; Voelter, W. Amino Acid Sequence and Glycosylation of Functional Unit RtH2-e from Rapana thomasiana (Gastropod) Hemocyanin. Arch. Biochem. Biophys. 2002, 399, 149-158. [CrossRef]

21. Stepan, H.; Pabst, M.; Altmann, F.; Geyer, H.; Geyer, R. O-Glycosylation of snails. Glycoconju-gate J. 2012, 29, 189-198. [CrossRef]

22. Gatsogiannis, C.; Moeller, A.; Depoix, F.; Meissner, U.; Markl, J. Nautilus pompilius hemocyanin: 9 A cryo-EM structure and molecular model reveal the subunit pathway and the interfaces between the 70 functional units. J. Mol. Biol. 2007, 374, 465-486. [CrossRef]

23. Stoeva, S.; Schütz, J.; Gebauer, W.; Hundsdörfer, T.; Manz, C.; Markl, J.; Voelter, W. Primary structure and unusual carbohydrate moiety of functional unit 2-c of keyhole limpet hemocyanin (KLH). Biochim. Biophys. Acta 1999, 1435, 94-109. [CrossRef]

24. Lieb, B.; Boisguérin, V.; Gebauer, W.; Markl, J. cDNA sequence, protein structure, and evolution of the single hemocyanin from Aplysia californica, an opisthobranch gastropod. J. Mol. Evol. 2004, 59, 536-545. [CrossRef] [PubMed]

25. Lieb, B.; Altenhein, B.; Markl, J. The sequence of a gastropod hemocyanin (HtH1 from Haliotis tuberculata). J. Biol. Chem. 2000, 275, 5675-5681. [CrossRef] [PubMed]

26. Dolashka-Angelova, P.; Beck, A.; Dolashki, A.; Stevanovic, S.; Beltramini, M.; Salvato, B.; Hristova, R.; Velkova, L.; Voelter, W. Carbohydrate moieties of molluscan Rapana venosa hemocyanin. Micron 2004, 35, 101-104. [CrossRef]

27. Idakieva, K.; Stoeva, S.; Voelter, W.; Gielens, C. Glycosylation of Rapana thomasiana hemocyanin. Comparison with other prosobranch (gastropod) hemocyanins. Comp. Biochem. Physiol. B Biochem. Mol. Biol. 2004, 138, 221-228. [CrossRef]

28. Beck, A.; Hillen, N.; Dolashki, A.; Stevanovic, S.; Salvato, B.; Voelter, W.; Dolashka-Angelova, P. Oligosaccharide structure of a functional unit RvH1-b of Rapana venosa hemocyanin using HPLC/electrospray ionization mass spectrometry. Biochimie 2007, 89, 938-949. [CrossRef] [PubMed]

29. Dolashka-Angelova, P.; Beck, A.; Dolashki, A.; Beltramini, M.; Stevanovic, S.; Salvato, B.; Voelter, W. Characterization of the carbohydrate moieties of the functional unit RvH1-a of Rapana venosa haemocyanin using HPLC/electrospray ionization MS and glycosidase digestion. Biochem. J. 2003, 374, 185-192. [CrossRef]

30. Dolashka-Angelova, P.; Stevanovic, S.; Dolashki, A.; Devreese, B.; Tzvetkova, B.; Voelter, W.; Van Beeumen, J.; Salvato, B. A challenging insight on the structural unit 1 of molluscan Rapana venosa hemocyanin. Arch. Biochem. Biophys. 2007, 459, 50-58. [CrossRef] [PubMed] 
31. Dolashka-Angelova, P.; Lieb, B.; Velkova, L.; Heilen, N.; Sandra, K.; Nikolaeva-Glomb, L.; Dolashki, A.; Galabov, A.S.; Van Beeumen, J.; Stevanovic, S.; et al. Identification of glycosylated sites in Rapana hemocyanin by mass spectrometry and gene sequence, and their antiviral effect. Bioconjugate Chem. 2009, 20, 1315-1322. [CrossRef] [PubMed]

32. Dolashka, P.; Velkova, L.; Shishkov, S.; Kostova, K.; Dolashki, A.; Dimitrov, I.; Atanasov, B.; Devreese, B.; Voelter, W.; Van Beeumen, J. Glycan structures and antiviral effect of the structural subunit RvH2 of Rapana hemocyanin. Carbohydr. Res. 2010, 345, 2361-2367. [CrossRef] [PubMed]

33. Sandra, K.; Dolashka-Angelova, P.; Devreese, B.; Van Beeumen, J. New insights in Rapana venosa hemocyanin $\mathrm{N}$-glycosylation resulting from on-line mass spectrometric analyses. Glycobiology 2007, 17, 141-156. [CrossRef] [PubMed]

34. Dolashka, P. Tandem Mass Spectrometry and Glycoproteins. In Tandem Mass Spectrometry—Applications and Principles; Prasain, J.K., Ed.; IntechOpen: Rijeka, Croatia, 2012; Chapter 6; pp. 105-127.

35. Dolashka-Angelova, P.; Schwarz, H.; Dolashki, A.; Stevanovic, S.; Fecker, M.; Saeed, M.; Voelter, W. Oligomeric stability of Rapana venosa hemocyanin $(\mathrm{RvH})$ and its structural subunits. Biochim. Biophys. Acta Proteins Proteom. 2003, 1646, 77-85. [CrossRef]

36. Velkova, L.; Dolashki, A.; Dolashka, P. Analysis of a glycopeptide from structural subunit $(\beta c-H l H)$ of Helix lucorum hemocyanin by mass spectrometry. In Proceedings of the Thirty-Third European Peptide Symposium, Sofia, Bulgaria, 31 August-5 September 2014; pp. 288-289.

37. Velkova, L.; Dolashki, A.; Dolashka, P. Carbohydrate structure of molluscan hemocyanins from snails Helix lucorum and Rapana venosa, determined by mass spectrometry. J. Biosci. Biotechnol. 2015, SE/ONLINE, 75-85.

38. Velkova, L.; Dolashka, P.; Van Beeumen, J.; Devreese, B. N-glycan structures of $\beta$ - HlH subunit of Helix lucorum hemocyanin. Carbohydr. Res. 2017, 449, 1-10. [CrossRef]

39. Velkova, L.; Dolashka, P.; Lieb, B.; Dolashki, A.; Voelter, W.; Van Beeumen, J.; Devreese, B. Glycan structures of the structural subunit (HtH1) of Haliotis tuberculata hemocyanin. Glycoconj. J. 2011, 28, 385-395. [CrossRef]

40. De Smet, L.; Dimitrov, I.; Debyser, G.; Dolashka-Angelova, P.; Dolashki, A.; Van Beeumen, J.; Devreese, B. The cDNA sequence of three hemocyanin subunits from the garden snail Helix lucorum. Gene 2011, 487, 118-128. [CrossRef]

41. Kostadinova, E.; Dolashka, P.; Velkova, L.; Dolashki, A.; Stevanovic, S.; Voelter, W. Positions of the glycans in molluscan hemocyanin, determined by fluorescence spectroscopy. J. Fluoresc. 2013, 23, 753-760. [CrossRef]

42. Cuff, M.E.; Miller, K.I.; van Holde, K.E.; Hendrickson, W.A. Crystal structure of a functional unit from Octopus hemocyanin. J. Mol. Biol. 1998, 278, 855-870. [CrossRef]

43. Perbandt, M.; Guthöhrlein, E.W.; Rypniewski, W.; Idakieva, K.; Stoeva, S.; Voelter, W.; Genov, N.; Betzel, C. The structure of a functional unit from the wall of a gastropod hemocyanin offers a possible mechanism for cooperativity. Biochemistry 2003, 42, 6341-6346. [CrossRef]

44. Altenhein, B.; Markl, J.; Lieb, B. Gene structure and hemocyaninisoform HtH2 from the mollusc Haliotis tuberculata indicate early and late intron hot spots. Gene 2002, 301, 53-60. [CrossRef]

45. Bergmann, S.; Lieb, B.; Ruth, P.; Markl, J. The hemocyanin from a living fossil, the cephalopod Nautilus pompilius: Protein structure, gene organization, and evolution. J. Mol. Evol. 2006, 62, 362-374. [CrossRef] [PubMed]

46. Salazar, L.M.; Jiménez, M.J.; Villar, J.; Rivera, M.; Báez, M.; Manubens, A.; Inés Becker, M. N-glycosylation of mollusk hemocyanins contributes to their structural stability and immunomodulatory properties in mammals. J. Biol. Chem. 2019, 294, 19546-19564. [CrossRef] [PubMed]

47. De Ioannes, P.; Moltedo, B.; Oliva, H.; Pacheco, R.; Faunes, F.; De Ioannes, E.A.; Becker, M.I. Hemocyanin of the molluscan Concholepas concholepas exhibits an unusual heterodecameric array of subunits. J. Biol. Chem. 2004, 279, 26134-26142. [CrossRef] [PubMed]

Publisher's Note: MDPI stays neutral with regard to jurisdictional claims in published maps and institutional affiliations. 